Provided for non-commercial research and education use. Not for reproduction, distribution or commercial use.

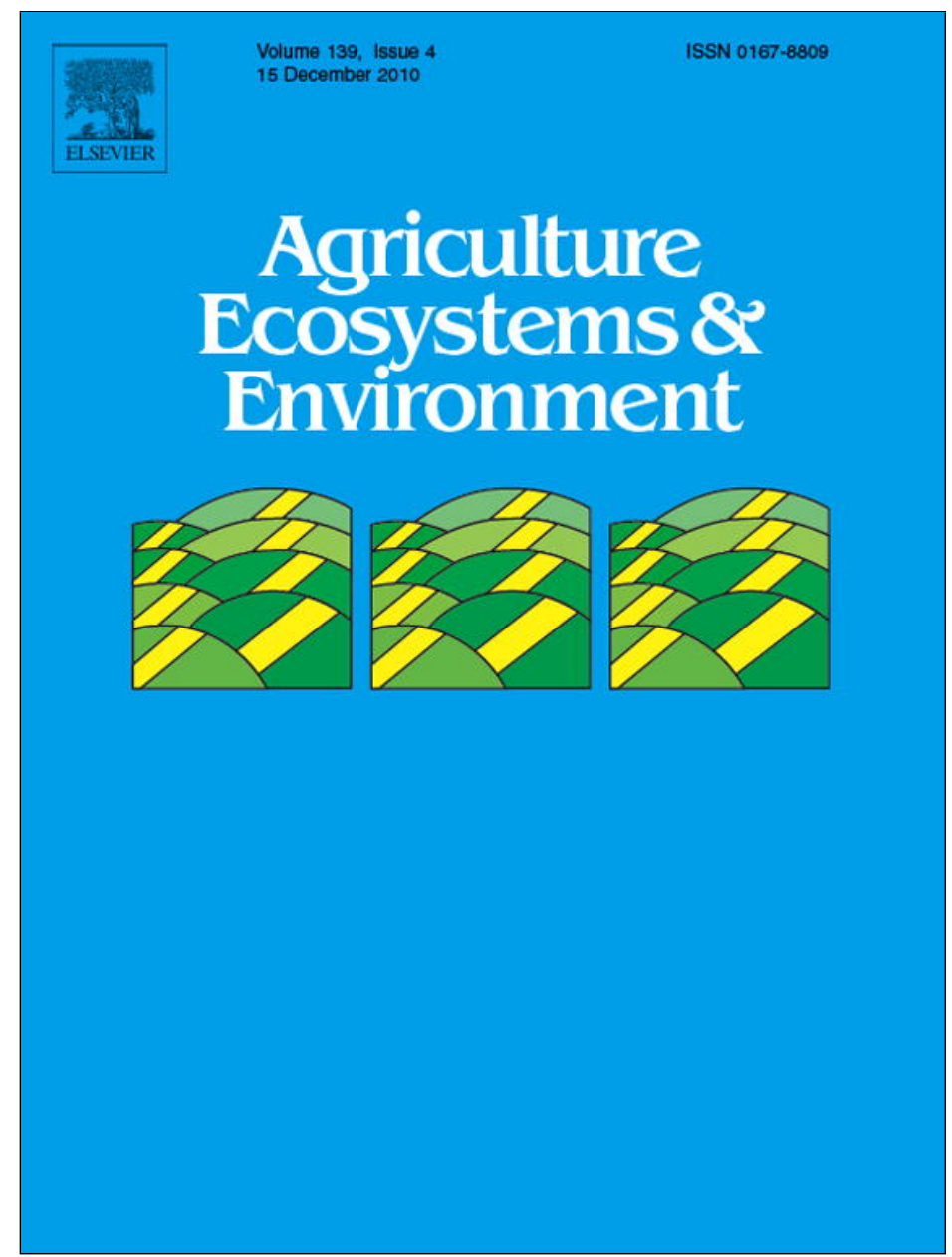

(This is a sample cover image for this issue. The actual cover is not yet available at this time.)

This article appeared in a journal published by Elsevier. The attached copy is furnished to the author for internal non-commercial research and education use, including for instruction at the authors institution and sharing with colleagues.

Other uses, including reproduction and distribution, or selling or licensing copies, or posting to personal, institutional or third party websites are prohibited.

In most cases authors are permitted to post their version of the article (e.g. in Word or Tex form) to their personal website or institutional repository. Authors requiring further information regarding Elsevier's archiving and manuscript policies are encouraged to visit:

http://www.elsevier.com/copyright 


\title{
Modelling the impact of climate change on the interaction between grapevine and its pests and pathogens: European grapevine moth and powdery mildew
}

\author{
Amelia Caffarra ${ }^{\mathrm{a}, *}$, Monica Rinaldi ${ }^{\mathrm{a}}$, Emanuele Eccel ${ }^{\mathrm{a}}$, Vittorio Rossi ${ }^{\mathrm{b}}$, Ilaria Pertot ${ }^{\mathrm{a}}$ \\ a IASMA Research and Innovation Centre, San Michele all'Adige, Trento, Italy \\ b Università Cattolica del Sacro Cuore, Piacenza, Italy
}

\section{A R T I C L E I N F O}

\section{Article history:}

Received 18 April 2011

Received in revised form

18 November 2011

Accepted 23 November 2011

\section{Keywords:}

Chardonnay

Erysiphe necator

Host

Lobesia botrana

Northern Italy

Pathogen

Pest

Projections

Synchrony

Viticulture

\begin{abstract}
A B S T R A C T
Climate change may impact patterns of plant diseases and arthropod development in more complex ways than expected. In fact, whereas both crops and crop pathogens and pests are affected by climatic variables, they might be influenced by different combinations of driving factors, and they might respond to their change at different rates. In order to separate these effects, we need to improve our understanding of the host-pest/pathogen system, and consider their interaction. The aim of this study was to refine current assessments of climate change impacts on pest and disease pressure on grapevines by considering pest/pathogen-host interactions. This research (i) combined detailed phenological models of grapevine with phenological models of one of its key insect pests (European grapevine moth) and one of its key pathogens (powdery mildew), (ii) applied the models to climate change scenarios for a selected study area in the eastern Italian Alps, and (iii) considered potential changes in their interactions. These simulations suggest that in the warmer, more profitable viticultural areas of the study region increasing temperature might have a detrimental impact on crop yield due to increased asynchrony between the larvae-resistant growth stages of grapevine and larvae of the European grapevine moth. On the other hand, the increase in pest pressure due to the increased number of generations might not be as severe as expected on the basis of the pest model only, due to the advance in harvest dates limiting damages from late-season generations. Simulations for powdery mildew highlighted a decrease in simulated disease severity, especially in years with a later onset of the disease symptoms and in the climate scenario with higher temperature increases.
\end{abstract}

(ㄷ) 2011 Elsevier B.V. All rights reserved.

\section{Introduction}

Major shifts in temperature and changes in the seasonal pattern of rainfall distribution are currently affecting most of the world. Climatic projections suggest that these trends will continue in the coming decades, affecting both mean and extreme values of these variables (Easterling et al., 2007). In the latest report of the Intergovernmental Panel on Climate Change (IPCC), mean global temperature is estimated to increase between 1.8 and $4.0^{\circ} \mathrm{C}$ (with a likely range of $1.1-6.4^{\circ} \mathrm{C}$ ), by the end of the present century, depending on the greenhouse gas emission scenario (Easterling et al., 2007). The combination of climate change, associated disturbances and other global change drivers is expected to exceed the resilience of many agro-ecosystems. As a consequence, climate change could substantially impact agriculture and food production (Olesen and Bindi, 2002; Fuhrer, 2003; Maracchi et al., 2005; Kang et al., 2009). The result of climatic change should not be always

\footnotetext{
* Corresponding author.

E-mail address: amelia.caffarra@gmail.com (A. Caffarra).
}

seen as a threat to farm productivity, especially where water is not a limiting factor. However, Olesen et al. (2011) pointed out that the perceived outcomes of climate change expected by European farmers remain mostly negative, and in particular, interviewed farmers disclosed the feeling that the risk from pests and diseases for grapevine will increase in the Alps (both north and south).

However, consequences of climate-driven changes are not easily predictable in complex agro-ecosystems, as the biology of pests and pathogens and that of their host plants are interdependent. For example, many pests/pathogens affect their host plant only during specific vulnerable periods of the plant life-cycle. This is the case of the pathogens that infect plants through their flowers, as the bacterium Erwinia amylovora, which can penetrate its hosts (e.g., apple and pear) during flowering (Thomson, 2000). Other pests might be able to attack their host throughout their growth season but cause higher damage during specific growth stages. For example, the larvae of European grapevine moth (Lobesia botrana) are less harmful during flowering (Gabel and Roehrich, 1995), but produce more damage in the post-veraison period, when they influence grey mould (Botrytis cinerea) infections (Moschos et al., 2004). Many plant species progressively increase their resistance to pests 
and pathogens as they age by developing "ontogenic" resistance, which may be active on the whole plant or in specific organs or tissues (Panter and Jones, 2002; Gadoury et al., 2003). For example, grape berries are reported to be susceptible to Erysiphe necator (the powdery mildew fungus) infections until soluble solids levels reach $8 \%\left(8^{\circ}\right.$ Brix), and the established fungal colonies are reported to sporulate until soluble solids levels reach $15 \%$ (15 ${ }^{\circ}$ Brix) (Delp, 1954; Chellemi and Marois, 1991).

Thus, in presence of pests, infestations will occur only under specific environmental conditions and only if the host plant is in a susceptible growth stage (Chakraborty et al., 2000). For pathogens, this interaction has been frequently represented by the "plant-disease triangle", which is made up by the three elements required for the infection to develop: a susceptible host, the presence of the pathogen, and a conducive environment (Chakraborty et al., 2000).

In addition to the above described "susceptibility windows", one should consider the duration of the productive cycle of each crop. In fact, while higher temperatures might favour the development of certain pests, they could also shorten the length of crop cycles, thus balancing out a potential increase in pest pressure. For example, higher temperatures might cause an increase in the number of generations of insect species that are able to produce several broods per year (multivoltine species). This would imply an increase in the number of reproductive events per year, leading to an increase in population, and increased levels of infestation (Yamamura and Yokozawa, 2002; Dukes et al., 2009). However, if the last generations emerge after a crop is harvested, they cannot impact crop yield, and pest population might decrease in size due to the absence of suitable food. Some pathogens are able to infect its hosts when the plants are in certain developmental stages. This means that in order to maximize their chance of infection, the life cycle of pathogen populations must be in synchrony with host development. Since climate change can influence the rate of both host and pathogen development, it could affect the development and impact of plant diseases. Some pathogen species may be able to maintain their synchrony with target host tissue, and others may become out of synchrony (Garrett et al., 2009).

While it is clear that all these factors respond to climatic variables, they might be controlled by different combinations of driving factors, or respond to their change at different rates. In order to separate these effects, we need to better assess the dynamical interactions of the host-pest/pathogen system. Indeed, meaningful projections of climate change impacts on disease/infestation pressure can be obtained only by coupling host phenology with patterns of pest development and infestation (Grulke, 2011). At present, only a few modelling studies have considered these interactions for the projection of climate change impacts on agriculture (Baker et al., 2005; Calonnec et al., 2008; Ponti et al., 2009; Gutierrez et al., 2009). In fact, most research has concentrated on the effects of climate change on either the physiology/phenology of single crops (see, for example Webb et al., 2008; Hall and Jones, 2008; Eccel et al., 2009; Caffarra and Eccel, 2011) or pests alone (see, for example Porter et al., 1991; Woiwod et al., 1997; Bale et al., 2002; Salinari et al., 2006; Estay et al., 2009). Whereas the pressure of pest/pathogen on their host plant will probably also depend on factors other than the direct effect of temperature on their development, such as genetic adaptation, the simulation of the effects of climate change on their phenological interaction is nonetheless useful to highlight possible trends in future disease/infestation patterns.

The aim of this study was to refine current assessments of climate change impacts on pest/pathogen occurrence on grapevines by simulating pest/pathogen-host interactions. This research (i) combines detailed phenological models of grapevine with phenological models of one of its key pests (Lobesia botrana, Den. and Schiff., Lepidoptera: Tortricidae) and one of its key pathogens [E.

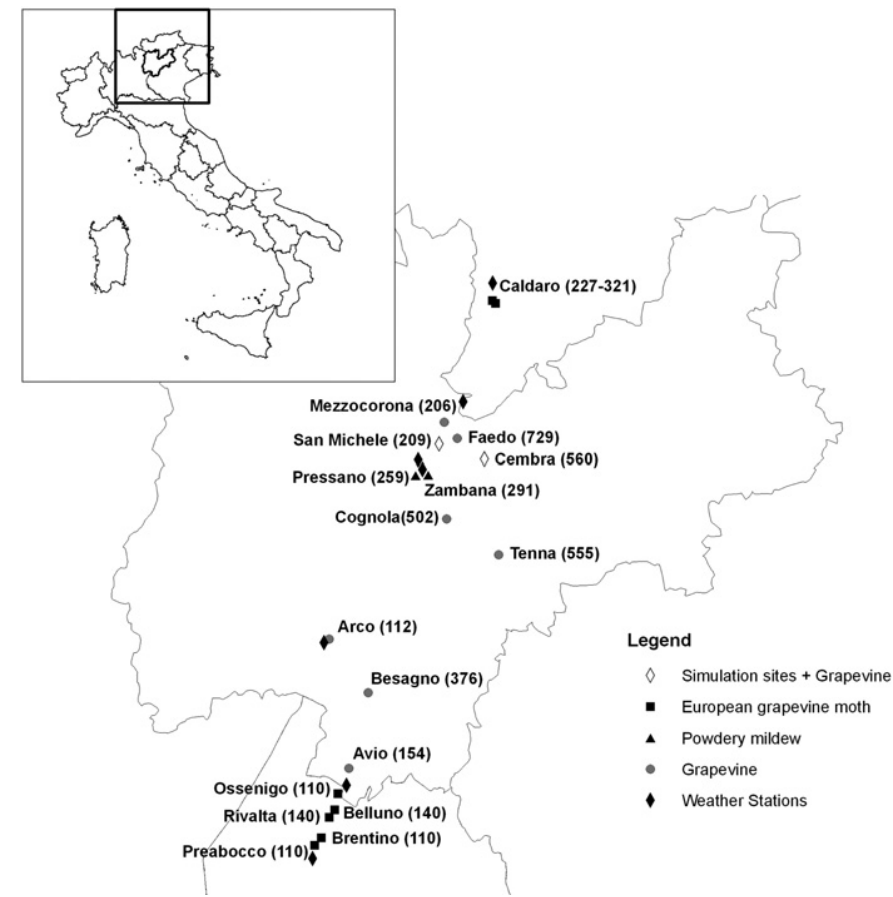

Fig. 1. Location of the meteorological stations used for the study, the simulation sites and the sites of provenance of the grapevine phenology, pest and pathogen observations used for model calibration and validation. The meteorological stations used to calibrate and validate the models for the sites of Cembra, San Michele, Besagno, Cognola, Faedo and Tenna were in close proximity (less than $1 \mathrm{~km}$ ) to the phenology/pest and disease monitoring sites and are not represented in the map for clarity. Between parenthesis (): elevation above sea level of each site. Inset: The Trento province is highlighted in bold at the centre of the square encompassing the study area.

necator, (Schw.) Burr.], (ii) apply the models to climate change scenarios for a selected study area (in the eastern Italian Alps (Fig. 1), and (iii) consider potential changes in the interactions in these two systems.

The European Grapevine moth (Lobesia botrana) is one of the most noxious vineyard-pests in the European and Mediterranean areas (Delbac et al., 2010). Its larvae feed on grapevine flowers and berries, with a facultative diapause and a variable number of generations per year, depending on temperature and photoperiod (Pavan et al., 2010). It is usually reported as being trivoltine in Mediterranean areas although, in the warmest years, a fourth partial generation has been reported (Torres-Vila et al., 2004). The first adults of $L$. botrana appear in the spring and are shortly followed by the first generation of larvae which feed on inflorescences and buds; in Northern Italy this occurs between May and June. Subsequent generations feed on berries and usually cause considerable damage (Moschos et al., 2004). However, the sensitivity of grapevines to infestation by this pest varies during the grape growing season (Gabel and Roehrich, 1995; Pavan et al., 2009). Gabel and Roehrich (1995) compared the damage produced by larvae infestation at different growth stages on different grapevine cultivars and observed for all stages a period in which fructiferous organs (flowers and berries) were unsuitable for infestation by freshly hatched larvae, i.e. flowering and fruit set. During this "resistant" phenological window, the level of damage caused by larvae was significantly lower compared to earlier and later growth stages.

Powdery mildew (E. necator) is one of the major diseases in grapevine (Gadoury et al., 2003; Bendek et al., 2007; Caffi et al., 2011). It affects green leaves and fruit and reduces the yield of grapes and the quality of must and wine (Gadoury et al., 2001; Campbell et al., 2006). This pathogen undergoes sexual and 
asexual cycles during the year, overwinters as mycelium in infected buds or chasmothecia in the bark of vines (Gadoury and Pearson, 1988; Cortesi et al., 1995). The primary infections are usually caused by the ascospores; afterwards, the disease progresses during the season by asexual, secondary infection cycles driven by conidia (Carisse et al., 2009). The severity of the disease is related to the number of disease cycles per season, by air humidity (a moderately high air humidity promotes the germination of conidia) and rainfall (rain prevents germination of conidia) (Carroll and Wilcox, 2003; Bendek et al., 2007). Asexual reproduction and rate of epidemic development of powdery mildew are mainly controlled by temperature (Delp, 1954; Sall, 1980; Chellemi and Marois, 1991). The length of the "latency period" of each cycle (i.e., the time period between spore deposition of the plant surface and sporulation of the resultant colony) is the main driver of the number of disease cycles, which is in turn affected by temperature (Calonnec et al., 2008). This latency period is minimum when temperatures are within the optimal range between 20 and $28^{\circ} \mathrm{C}$ (Caffi et al., 2011).

\section{Methods}

\subsection{Study area and sites}

The study area is in the pre-alpine and alpine viticultural regions along the Adige River in the central-eastern Italian Alps, and includes part of the provinces of Verona, Trento and Bolzano (Fig. 1). This mountainous area consists of a system of minor valleys converging to the largest and longest of them, the Adige Valley.

Viticulture is an important source of revenue for this region and forms part of its historical and social identity, with evidence of vine-growing dating back to the Roman period. Chardonnay is one of the most widely grown varieties. In the province of Trento, at the core of the study area, this variety is grown on about onethird of the total viticultural area and is used to produce still and "classic-method", sparkling wine, called "spumante". Commercial vineyards of Chardonnay are grown between about 100 and $700 \mathrm{~m}$ a.s.l.

For this work, two study sites were chosen in the Trento province (Fig. 1). The first is in San Michele all'Adige and is located in the Adige valley floor; the second is in Cembra and is located at a higher elevation on a mountain slope. These two sites are representative of the low and mid-high elevation viticultural environment, respectively. The Adige valley floor is one of the most profitable viticultural areas of the region because of the quality of grapes and the relative ease of viticultural practices due to its flat terrain.

\subsection{Host and pest/pathogen models}

\subsubsection{Grapevine}

2.2.1.1. Model description. In order to simulate susceptibility windows and ontogenic resistance to pests we adopted an existing phenological model, named FENOVITIS (Caffarra and Eccel, 2010), which simulates the following growth stages: (i) budburst (stage $\mathrm{BBCH} 08$ ); (ii) flowering (stage $\mathrm{BBCH} 65$ ), and (iii) veraison (stage BBCH 81). The FENOVITIS model considers the action of cool (chilling) temperatures for dormancy release, and the action of warm (forcing) temperatures for subsequent bud growth. It describes plant development in terms of developmental units, calculated through fitted or experimentally measured relationships: chilling units are accumulated up to a critical chilling threshold simulating dormancy release, which is followed by the accumulation of heat (forcing) units up to a critical forcing threshold, simulating budburst. The inclusion of chilling and the use of an experimentally established relationship for quantifying the action of warm temperatures on growth, makes the FENOVITIS model comparatively more process-based than the phenological models based on growing degree-days or other bioclimatic indices. When this model was validated on datasets from four different sites from Northern Italy, it yielded smaller prediction errors than the model based on growing degree days, and showed a better performance during warm years, suggesting its reliability when applied to climate change scenarios (Caffarra and Eccel, 2010).

2.2.1.2. Model calibration and validation. In order to extend the FENOVITIS model to include the growth stages which define the beginning and end of the plant susceptibility to European grapevine moth and powdery mildew, we collected data through a monitoring survey in 2009 and 2010. Data on the prevalent BBCH growth stage were collected weekly or bi-weekly, on nine Chardonnay vineyards sited at different altitudes (Fig. 1), in order to cover a wide climatic gradient. Temperature data were obtained from meteorological stations close to the vineyards ( $<2 \mathrm{~km}$ away). Mean temperature during the period April-September (during 2000-2010) at these sites ranged from $19^{\circ} \mathrm{C}$ in Avio to $15.8^{\circ} \mathrm{C}$ in Faedo. Starting from the beginning of July, once a week approximately 60 berries (randomly collected) were sampled in each vineyard to analyse the soluble solids.

We randomly selected half of the data collected during the monitoring surveys of 2009 and 2010 to calibrate the heat requirements of the growth stages of interest, fixing simulated budburst as the starting point. Heat units (HU) were calculated using the FENOVITIS model, as follows:

$\mathrm{HU}=\frac{1}{1+e^{-0.26\left(T_{\mathrm{m}}-16.06\right)}}$

where $T_{\mathrm{m}}=$ mean daily temperature.

With this approach, we quantified the heat requirements of BBCH phases: (i) 61 (beginning of flowering), (ii) 71 (fruit set), (iii) $8^{\circ}$ Brix, and (iv) $21^{\circ}$ Brix (which was considered as an indicator of the "berries ripe for harvest" phenophase, i.e., BBCH 89). These phase-specific heat requirements were calibrated using the Metropolis algorithm, already used for this purpose by Caffarra and Eccel (2010). The Metropolis algorithm (Metropolis et al., 1953), in contrast to traditional numerical methods such as the Downhill simplex and the Newton methods, enables a more effective exploration of the parameter space in functions with many local "minima", as is the case in phenological models (Chuine et al., 1998). The remaining half of the data was used to validate these sub-models. The adopted indicator of model performance was the mean absolute error (MAE).

\subsubsection{European Grapevine moth}

2.2.2.1. Model description. To simulate the phenology of the European grapevine moth, we adopted the approach of Cossu et al. (1999), who joined two sub-models, one sub-model for the simulation of adult flights (Arca et al., 1993) and one for the simulation of larval stages (Cossu et al., 1999). The sub-model for adult flights is based on the accumulation of growing degree-days (GDDs), which are calculated using the double sine method (Coop, 2009), relying on the previous day's maximum and the current day's minimum temperature for the first half of the day, and the current day's maximum and minimum temperature of the day for the second half of the day. GDDs were calculated adopting a lower threshold temperature of $8^{\circ} \mathrm{C}$ and upper threshold of $28^{\circ} \mathrm{C}$ (Cossu et al., 1999), and calculated from the 1 st of January to the attainment of each flight-specific heat requirements, estimated by Arca et al. (1993).

The model for larval emergence is based on an empirical relationship linking the rate of development of eggs with temperature. 
This relationship is expressed by the Logan curve (Logan et al., 1976):

$v(T)=a\left(e^{b\left(T-T_{\text {inf }}\right)}-e^{b\left(T_{\text {sup }}-T_{\text {inf }}\right)-c\left(T_{\text {sup }}-T\right)}\right)$

where: $v(T)=$ rate of egg development; $T$ = mean daily temperature; $a, b, c, T_{\text {sup }}$ and $T_{\text {inf }}=$ parameters to be calibrated using observations of larval stages. We used the parameters calibrated and validated by Cossu et al. (1999) using the rate of larval emergence at different temperatures (Rapagnani et al., 1988): $a=0.29737 ; b=0.18337$; $c=0.18798 ; T_{\text {inf }}=10^{\circ} \mathrm{C} ; T_{\text {sup }}=35^{\circ} \mathrm{C}$.

Cossu et al. (1999) linked the model for larval stages with the model for adult flights assuming that there are three days between the beginning of the flight and the start of oviposition. Because we were interested in the number of generations occurring before diapause, we stopped the simulation of larval emergence at the time of the year when photoperiod $\leq 12 \mathrm{~h}$ (approximated as $21 \mathrm{st}$ September) as different studies report a critical photoperiod for diapause induction between 13 and $12 \mathrm{~h}$ (Roehrich, 1969; Deseo et al., 1981; Roditakis and Karandinos, 2001).

2.2.2.2. Model validation. We adopted the model with the parameters originally calibrated by Cossu et al. (1999). In order to validate it for the study area, we ran the model using temperature series from local meteorological stations and compared model output to European grapevine moth catches at six sites ( 381 observations in total) located in the southern and northern areas of the region (Fig. 1). Most observations came from the southern areas of the study region (267 southern observations against 114 northern observations). The temperature series came from the meteorological stations of Caldaro for the northern sites and Preabocco and Avio for the southern sites. Of these six sites, five had observations during the period from 2006 to 2009, and at the remaining site (Caldaro) during two periods: 2001-2005 and 2008-2009. At the five sites, traps were monitored with a weekly frequency from the first week of May to the last week of August each year. In Caldaro, traps were monitored with a daily frequency from the beginning of June to the end of July, thus covering only the period of the second generation flight. In addition, at this station, the monitoring site was moved from its initial position (Caldaro-site 1 ) to a slightly more elevated position (Caldaro-site 2) after 2005 (Menke, 2007). The name and the altitude of each site are given in Fig. 1.

The model was operated for the six monitoring sites; we simulated up to four yearly flight periods, not overlapping and taking place from May to September. The simulated weekly presence/absence of flight was compared with the weekly observations (presence/absence of insects in the traps) using contingency tables. Predicted flight periods $(\mathrm{P})$ were compared with observed flight periods ( $\mathrm{O}$ ); all the possible combinations of $\mathrm{P}$ vs. $\mathrm{O}$ were organized in a $2 \times 2$ contingency table with the following categories: (i) true positives (TP), when the model correctly predicts the occurrence of flight; (ii) true negatives (TN), when the model correctly predicts the absence of flight; (iii) false positives (FP), when the model predicts flight occurrence but no adults were trapped in that period; (iv) false negatives (FN), when the model predicts flight absence but a flight is observed. We adopted the "overall accuracy" (a measure of the percentage of correctly classified instances) as a measure of model performance as follows:

Overall accuracy $=(\mathrm{TP}+\mathrm{TN}) /(\mathrm{TP}+\mathrm{TN}+\mathrm{FP}+\mathrm{FN})$

Sensitivity, specificity and likelihood ratios of the model predictions were evaluated by means of Bayesian analysis (Yuen and Hughes, 2002).

\subsubsection{Powdery mildew}

2.2.3.1. Model description. A model for powdery mildew epidemics in the study area was developed based on the relationship between: (i) the severity of powdery mildew epidemics on bunches and (ii) the number of infection cycles occurring during the powdery mildew-susceptible growth stages of the grapevine plants, i.e. between budburst and $8^{\circ}$ Brix (Delp, 1954; Chellemi and Marois, 1991).

Disease severity was assessed at weekly intervals between May and August, in 2002-2008, in two untreated Chardonnay vineyards in the study area, at Pressano, on a hill-slope, and Zambana, in the valley floor (Fig. 1). The observations reported the percentage of diseased area (i.e., disease severity), which was visually estimated on 100 random leaves from May to harvest (BBCH89), and 100 random bunches from flowering (BBCH65) until harvest (BBCH89). Disease assessments on bunches were averaged to provide weekly disease severity for the two sites.

The number of cycles between budburst (simulated using the FENOVITIS model) and August was calculated based on the length of the latency period of $E$. necator, using the equation developed by Caffi et al. (2011) as a part of a mechanistic model for the occurrence of primary infections; the model of Caffi et al. (2011) was validated in Italy, in northern (i.e. Piedmont and Lombardy), central (i.e. Marche and Emilia Romagna), and southern regions (i.e. Basilicata). This equation was developed by fitting experimental data on the relationship between temperature and duration of the latency period (Delp, 1954; Analytis, 1980; Chellemi and Marois, 1991; Calonnec et al., 2008) by a polynomial in such a way that latency duration is minimal at the optimal temperature of $22-27^{\circ} \mathrm{C}$ (Pearson and Goheen, 1988; Fernandez-Gonzalez et al., 2009; Caffi et al., 2011) and increases at sub-optimal temperatures above or below this range. In detail, the daily progress of latency (LATP) is calculated as follows:

$\operatorname{LATP}_{i}=\frac{1}{\operatorname{LAT}_{i}} ; \operatorname{LAT}_{i}=\gamma+\psi T_{i}-\tau T_{i}^{2}$

with $\gamma=44.7 ; \psi=0.067 ; \tau=3.244 ; T=$ mean daily temperature $\left({ }^{\circ} \mathrm{C}\right)$; $i=$ day of the year.

Starting from budburst, LATP $i$ was accumulated daily; when LATP $_{i} \geq 1$, sporulation starts on the powdery mildew colonies and a new disease cycle starts over.

The disease model is based on a logistic equation, in the following form:

$\mathrm{DS}=\frac{c}{1+e^{a-b \mathrm{NC}}}$

where DS = disease severity on bunches; $\mathrm{NC}=$ number of infection cycles; $a, b, c=$ model parameters.

2.2.3.2. Model calibration. Parameters of Eq. (4) were estimated for the epidemics which develop under two scenarios of conduciveness for the disease: (i) high conduciveness and (ii) low-intermediate conduciveness. The "disease conduciveness" concept accounts for all the variables affecting the disease development, other than the weather (e.g., level of overwintered inoculum, training system, vine vigour), which were not specifically considered in this work. The disease severity data of the observed vineyards with a final disease severity $\geq 95 \%$ were used for the first scenario, while vineyards with a final disease severity between 26.7 and $64.3 \%$ were used for the second scenario. Only disease severity observations taken on grapevine bunches was used to develop the model. The model parameters for the two scenarios were estimated by the non-linear regression procedure of SPSS (ver. 15, SPSS Inc.), which minimizes the residual sums of squares using the Marquardt algorithm. The following were used as indicators of goodness-of-fit: the magnitude of the standard errors of the model parameters, the coefficient of determination adjusted for the degrees of freedom, the number of iterations required by the Marquardt algorithm to converge on parameter estimates, and the magnitude and 
Table 1

Parameter estimates (heat units) and performance of the extended FENOVITIS model. Mean, Max, Min and SD: mean, maximum, minimum values and standard deviations of the observed and simulated phenophase dates (day of the year). $\mathrm{N}(\mathrm{cal})$ : number of observations in the calibration dataset. $\mathrm{N}$ (val) number of observations in the validation dataset. MAE(cal): mean absolute error of the model predictions on the calibration dataset (internal MAE); MAE(val): mean absolute error of the model predictions on the validation dataset (external MAE); $\mathrm{BBCH} 61$ : beginning of flowering; $\mathrm{BBCH} 71$ : end of flowering/fruit set; $8^{\circ}$ Brix: attainment of $8^{\circ}$ Brix; $21^{\circ}$ Brix: attainment of $21^{\circ}$ Brix.

\begin{tabular}{|c|c|c|c|c|c|c|c|c|c|c|c|c|c|}
\hline \multirow[t]{2}{*}{ Submodel } & \multicolumn{4}{|c|}{ Observations } & \multicolumn{4}{|c|}{ Simulations } & \multirow[t]{2}{*}{ Heat units } & \multirow[t]{2}{*}{$\mathrm{N}(\mathrm{cal})$} & \multirow[t]{2}{*}{$\mathrm{N}(\mathrm{val})$} & \multirow[t]{2}{*}{$\operatorname{MAE}(\mathrm{cal})$ (days) } & \multirow[t]{2}{*}{$\operatorname{MAE}($ val) (days) } \\
\hline & Mean & Max & Min & SD & Mean & Max & Min & SD & & & & & \\
\hline BBCH61 & 152.8 & 161 & 147 & 4.9 & 153.4 & 164 & 148 & 5.5 & 21.59 & 4 & 5 & 0.9 & 2.1 \\
\hline ВBCH71 & 165 & 176 & 160 & 5.2 & 167.1 & 182 & 161 & 6.7 & 32.03 & 4 & 5 & 1.0 & 2.5 \\
\hline $8^{\circ}$ Brix & 211.9 & 230 & 200 & 8.7 & 210.5 & 233 & 198 & 9.6 & 67.61 & 9 & 9 & 5.1 & 1.9 \\
\hline $21^{\circ}$ Brix & 245.8 & 269 & 235 & 10.0 & 248.4 & 292 & 230 & 17.6 & 95.71 & 9 & 9 & 2.7 & 3.9 \\
\hline
\end{tabular}

distribution of residuals (data not shown). The estimated parameters for high and low-intermediate conduciveness scenarios were: (i) $a=9.119 \pm 1.861, b=0.998 \pm 0.207, c=0.98 \pm 0.015\left(R^{2}=0.93\right)$; (ii) $a=14.632 \pm 2.067, b=1.214 \pm 0.257, c=0.49 \pm 0.118\left(R^{2}=0.95\right)$. The indicated asymptotic standard errors $( \pm)$ account for the variability in estimating the model parameters with a non-linear regression procedure.

\subsection{Meteorological data and temperature projections}

Meteorological data (daily minimum and maximum temperature) to use as inputs in the grapevine and pest/pathogen model were obtained from four different weather station networks belonging to: the Agenzia Regionale per la Prevenzione e Protezione Ambientale of the Veneto region (Verona province); the Servizio Meteorologico of the autonomous province of Bolzano, the Südtiroler Beratungsring für Obst- und Weinbau (Bolzano province); and the Fondazione E. Mach (Trento province). Weather stations were located between 0 and $5 \mathrm{~km}$ from the monitoring sites (Fig. 1).

For the simulation of future climate, we used statistically downscaled temperature series based on the output of the Hadley Centre's Atmosphere-Ocean General Circulation Model (AOGCM) HADCM3 (Pope et al., 2000). The comparison of the model outputs from the CMIP - Coupled Model Intercomparison Project (http://cmip-pcmdi.llnl.gov/) shows that HADCM3s temperature projection is in the average of five benchmark models from 2000 to the years 2040s for A2 scenario, and slightly increases above the group average after the first half of the century. The downscaling procedure used in this work was previously described by Caffarra and Eccel (2010). The model output had a resolution of $2.5^{\circ}$ latitude by $3.75^{\circ}$ longitude. The statistical downscaling algorithm was a daily-resolution "transfer function method" (Eccel et al., 2009), applied series by series.

We considered the A2 and B2 scenarios, downscaled for the stations of San Michele (representative of the valley floor environment) and Cembra (representative of the mountain slope environment at higher elevation) for the period 1990-2080. These two scenarios are from IPCC's "Special Report on Emission Scenarios" - SRES (Nakicenovic and Swart, 2000) and represent two intermediate hypotheses on the increase in concentration of greenhouse gases (GHG). Whereas both scenarios show a moderate temperature increase from today to 2050 , afterwards, the A2 scenario warms up abruptly while the B2 scenario maintains a constant but moderate temperature increase. The A2 storyline and scenario family describes a very heterogeneous world, whose emission rates in general do not stay within the bounds of any self-regulation. The underlying theme is self-reliance and preservation of local identities. Economic development is primarily regionally oriented and per capita economic growth and technological change are more fragmented. The B2 storyline and scenario family assumes the adoption of self-imposed standards of reduction in the emissions. It describes a world in which the emphasis is on local solutions to economic, social, and environmental sustainability. It is a world with continuously increasing global population at a lower rate than in $\mathrm{A} 2$, intermediate levels of economic development, and less rapid and more diverse technological change than in the B1 and A1 storylines. At the end of the simulation period, mean annual temperatures in the study region are projected to exceed present values by about 2 and $4.5^{\circ} \mathrm{C}$, respectively in the $\mathrm{B} 2$ and $\mathrm{A} 2$ scenarios.

\subsection{Analysis}

First, we evaluated the projections for European grapevine moth and powdery mildew; second, we combined them with grapevine phenology projections, and finally we considered the interaction among the pest, the disease and the host. The model projections were visually evaluated using scatter plots. Ten-year moving averages were applied to the projected series to visually assess temporal trends. To determine the overall significance of trends, we fitted linear models to the simulated data over the projection period. Censored regression was applied wherever the variable of interest was observable only within a defined interval such as for percentage data (Schnedler, 2005).

In order to define the percentage of temporal overlap between the European grapevine moth larvae-resistant growth stages of grapevine (flowering and fruit set, BBCH61 to 71) and the moth larval stage, we considered the number of days during which both larvae and the larvae-resistant growth stages occurred (co-occurrence days) and calculated the percentage of overlap as: ((number of co-occurrence days)/(duration of the resistant phenophase) $) \times 100$.

The number of larval generations before harvest was calculated adopting $21^{\circ} \mathrm{Brix}$ as an indicator of harvest. When, according to the simulations, this stage occurred in the middle of a larval generation (i.e. after the onset of larvae, but before their end), we calculated the percent portion of larval generation occurring before harvest as: ((number of days from the beginning of larval emergence to $\left.21^{\circ} \mathrm{Brix}\right) /($ total duration of larval generation $\left.)\right) \times 100$. This ratio expressed the time lapse during which larvae co-occurred with ripe berries as a fraction of the total duration of the larval generation.

For powdery mildew, we produced projections of disease severity for both low-intermediate and high disease conduciveness scenarios and evaluated the impact of temperature increase on disease epidemics in relation with grapevine phenology.

\section{Results}

\subsection{Validation of pest and host models}

In the study area flowering usually occurs at the beginning of June and lasts around 10-14 days (period between beginning of flowering and fruit set) depending on the elevation. Ripening occurs between the end of August (valley floor, on warm years) and the end of September (mountain slopes, on cool years) (Table 1). 
Table 2

Overall accuracy and likelihood ratios of the European grapevine moth model predictions (adult flights) using observations from six vineyards in the study area. The observation period ranges between 2001 and 2009.

\begin{tabular}{|c|c|c|c|c|c|c|c|c|}
\hline \multirow[t]{2}{*}{ Observed } & \multicolumn{2}{|l|}{ Predicted } & \multirow[t]{2}{*}{ Total } & \multirow[t]{2}{*}{ Overall accuracy $^{\mathrm{a}}$} & \multirow[t]{2}{*}{ Likelihood ratio (LR) } & \multirow[t]{2}{*}{ Prior probability $(P)$} & \multicolumn{2}{|c|}{ Posterior probability $(P)$} \\
\hline & Yes $(\mathrm{P}+)$ & No $(\mathrm{P}-)$ & & & & & & \\
\hline Yes $\left(\mathrm{O}^{+}\right)$ & $222(0.9)^{b}$ & $33(0.1)^{c}$ & 255 & 0.80 & LR $\left(\mathrm{O}^{+}\right) 2.6$ & $\mathrm{P}(\mathrm{O}+) 0.67$ & $\mathrm{P}(\mathrm{O}+, \mathrm{P}+) 0.84$ & $\mathrm{P}(\mathrm{O}+, \mathrm{P}-) 0.28$ \\
\hline No $\left(\mathrm{O}_{-}\right)$ & $43(0.3)^{d}$ & $83(0.7)^{\mathrm{e}}$ & 126 & & $\operatorname{LR}\left(\mathrm{O}_{-}\right) 0.2$ & $\mathrm{P}\left(\mathrm{O}_{-}\right) 0.33$ & $\mathrm{P}(\mathrm{O}-, \mathrm{P}+) 0.16$ & $\mathrm{P}(\mathrm{O}-, \mathrm{P}-) 0.72$ \\
\hline Total & 265 & 116 & 381 & & & & & \\
\hline
\end{tabular}

a $(\mathrm{TP}+\mathrm{TN}) /(\mathrm{TP}+\mathrm{TN}+\mathrm{FP}+\mathrm{FN})$.

b True positive proportion, TPP (sensitivity).

c False negative proportion, FNP.

d False positive proportion, FPP (minus the specificity).

e True negative proportion, TNP (specificity).

Table 3

Rates of change in the timing of phenophases over the simulation period (day $\mathrm{yr}^{-1}$ ) (slope), $R^{2}$ of the linear regression model fitted to the simulated phenological series and mean phenophase dates \pm standard deviation, simulated over the decades 1991-2000 and 2071-2080, for each site and scenario.

\begin{tabular}{|c|c|c|c|c|c|c|}
\hline \multirow[t]{2}{*}{ Site } & \multirow[t]{2}{*}{ Scenario } & \multirow[t]{2}{*}{ Phenophase } & \multirow[t]{2}{*}{ Slope } & \multirow[t]{2}{*}{$R^{2}$} & \multicolumn{2}{|c|}{ Mean phenophase date } \\
\hline & & & & & 1991-2000 & 2071-2080 \\
\hline San & A2 & ВBCH08 & -0.091 & $0.102^{*}$ & $101.0 \pm 8.7$ & $94.2 \pm 7.8$ \\
\hline \multirow{9}{*}{ Michele } & & BBCH61 & -0.181 & $0.343^{* *}$ & $152.8 \pm 7.6$ & $135.2 \pm 5.8$ \\
\hline & & BBCH71 & -0.207 & $0.399^{* *}$ & $168.5 \pm 6.4$ & $148.8 \pm 6.0$ \\
\hline & & $8^{\circ}$ Brix & -0.268 & $0.565^{* *}$ & $213.8 \pm 7.2$ & $188.4 \pm 6.2$ \\
\hline & & $21^{\circ}$ Brix & -0.374 & $0.623^{* *}$ & $250.8 \pm 9.5$ & $220.2 \pm 6.0$ \\
\hline & B2 & ВВСH08 & -0.026 & 0.010 & $100.9 \pm 5.9$ & $96.6 \pm 7.3$ \\
\hline & & BBCH61 & -0.153 & $0.268^{* *}$ & $153.9 \pm 3.1$ & $137.5 \pm 4.9$ \\
\hline & & BBCH71 & -0.158 & $0.289^{* *}$ & $168.3 \pm 3.1$ & $152.3 \pm 4.4$ \\
\hline & & $8^{\circ}$ Brix & -0.290 & $0.489^{* *}$ & $92.0 \pm 3.9$ & $72.7 \pm 4.4$ \\
\hline & & $21^{\circ}$ Brix & -0.290 & $0.499^{* *}$ & $252.2 \pm 6.0$ & $226.1 \pm 4.8$ \\
\hline \multirow[t]{10}{*}{ Cembra } & $\mathrm{A} 2$ & ВBCH08 & -0.096 & $0.127^{* *}$ & $100.9 \pm 6.6$ & $92.7 \pm 7.7$ \\
\hline & & BBCH61 & -0.186 & $0.368^{* *}$ & $149.4 \pm 8.1$ & $130.6 \pm 6.6$ \\
\hline & & ВBCH71 & -0.237 & $0.453^{* *}$ & $166.7 \pm 6.7$ & $143.4 \pm 6.6$ \\
\hline & & $8^{\circ}$ Brix & -0.335 & $0.644^{* *}$ & $213.8 \pm 7.2$ & $186.8 \pm 6.6$ \\
\hline & & $21^{\circ}$ Brix & -0.658 & $0.709^{* *}$ & $272.3 \pm 15.5$ & $218.1 \pm 7.4$ \\
\hline & B2 & $\mathrm{BBCHO}$ & -0.032 & 0.017 & $102.0 \pm 5.4$ & $95.4 \pm 4.3$ \\
\hline & & $\mathrm{BBCH} 61$ & -0.182 & $0.294^{* *}$ & $156.3 \pm 4.4$ & $134.8 \pm 4.1$ \\
\hline & & ВBCH71 & -0.193 & $0.318^{* *}$ & $171.9 \pm 5.0$ & $151.8 \pm 4.5$ \\
\hline & & $8^{\circ}$ Brix & -0.245 & $0.477^{* *}$ & $219.2 \pm 5.3$ & $169.0 \pm 4.8$ \\
\hline & & $21^{\circ}$ Brix & -0.468 & $0.528^{* *}$ & $270.6 \pm 2.5$ & $228.2 \pm 4.6$ \\
\hline
\end{tabular}

$p<0.01$.

The predicting performance of the sub-models for grapevine phenological susceptibility was considered satisfactory as they yielded Mean Absolute Errors (MAEs) that were lower than the monitoring resolution, which was 7 days for phenophase $8^{\circ}$ Brix and $21^{\circ}$ Brix and 3-4 days for BBCH 61 and 71 (Table 1). There was a reasonable agreement between simulated and observed number of total generations for the period 1991-2010, as in the study area usually $2-3$ generations of moths are observed each year (Anfora et al., 2007) similar to the mean 2.2-2.8 generations simulated in Cembra and San Michele over the same period.

The European grapevine moth model showed high overall accuracy (80\%), sensitivity (0.9), and specificity (0.7). This implies that it was able to correctly predict flights and absence of flights most of the time, as confirmed by the large positive likelihood ratio (2.6) and the small negative likelihood ratio (0.2). The model showed a slightly better performance when predicting flight presence $[\mathrm{P}(\mathrm{O}+\mathrm{P}+)=0.84]$ than flight absence $\left[\mathrm{P}\left(\mathrm{O}_{-}, \mathrm{P}-\right)=0.72\right]($ Table 2$)$. The probability of mispredicting the occurrence of flights is also reasonably low $(\mathrm{P}(\mathrm{O}+, \mathrm{P}-)=0.28)$. Whereas most observations came from the southern areas of the study region (267 southern observations against 114 northern observations), the overall accuracy of the model was similar when calculated separately for the two regions ( $88 \%$ vs. $74 \%$, for southern and northern observations, respectively).

\subsection{Projections}

\subsubsection{Grapevine}

All growth stages showed a trend towards earlier occurrence, but were more pronounced in summer (i.e., attainment of 8 and $21^{\circ} \mathrm{Brix}$ ) and for the mountain site of Cembra. In general, the projected rates of advance were stronger for the A2 scenario, due to its larger projected temperature increase (Table 3 ). These trends were all highly significant except for budburst (BBCH08) for the B2 scenario at both sites. When comparing the 1990s with the 2070s, simulated harvest dates advanced by 25 days (San Michele, B2) up to 32 days (Cembra, A2). The mean duration of flowering (BBCH61 to 71) at the beginning of the simulated period was about 15-16 and 15.5-17 days in San Michele and Cembra, respectively (B2 and A2 scenarios, respectively), but decreased only slightly in the B2 scenario, to 13.5 and 16 days in San Michele and Cembra, respectively (mean duration for the 2070s). During this period, the beginning of flowering advanced by between 14 and 23 days (San Michele, B2 and Cembra, A2), corresponding to a shift from the first week of June to the second-third week of May.

\subsubsection{European grapevine moth}

Whereas both the total number of larval generations and the number of larval generations before harvest (pre-harvest generations) increased over the simulation period, this trend was clearly 
San Michele A2

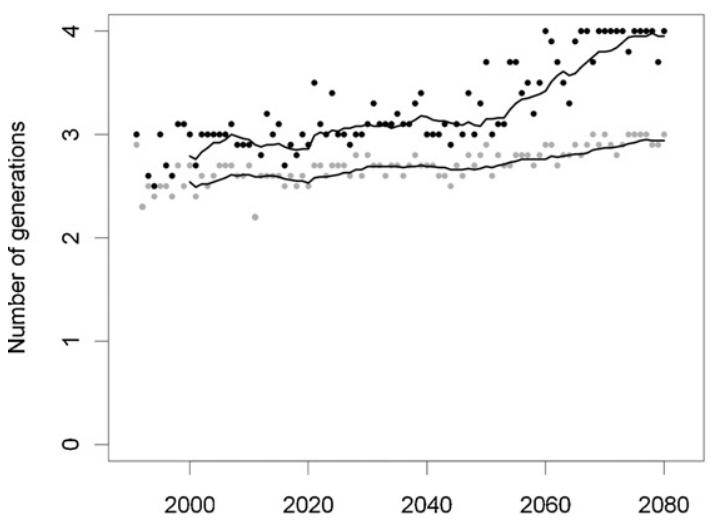

Cembra $A 2$

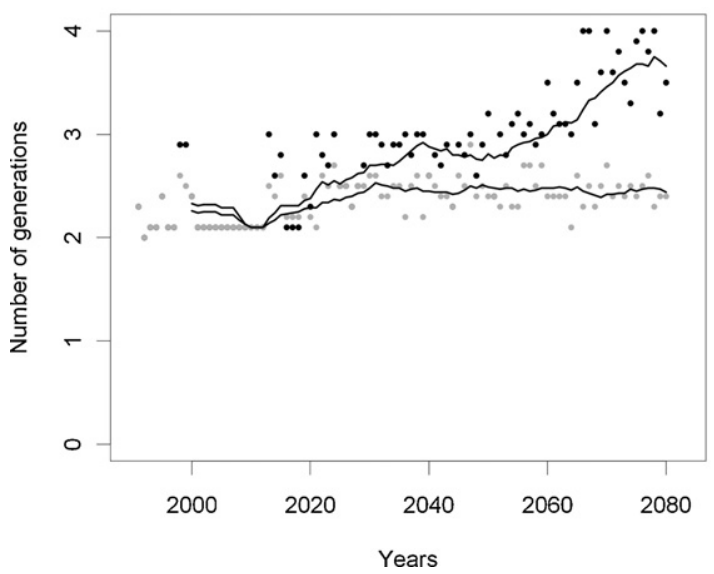

San Michele B2

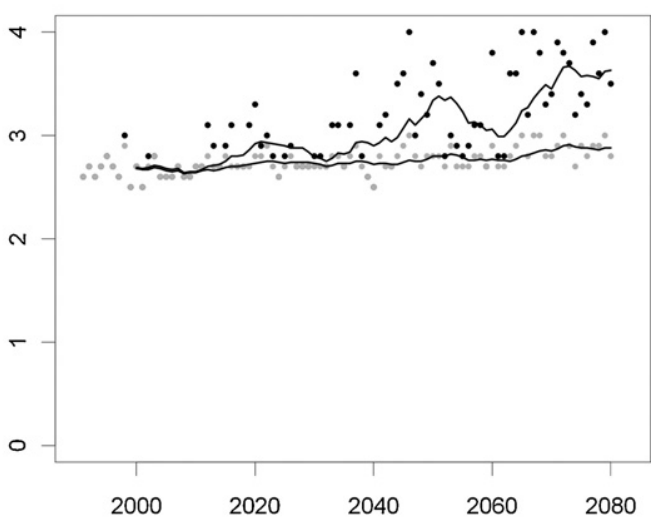

Cembra B2

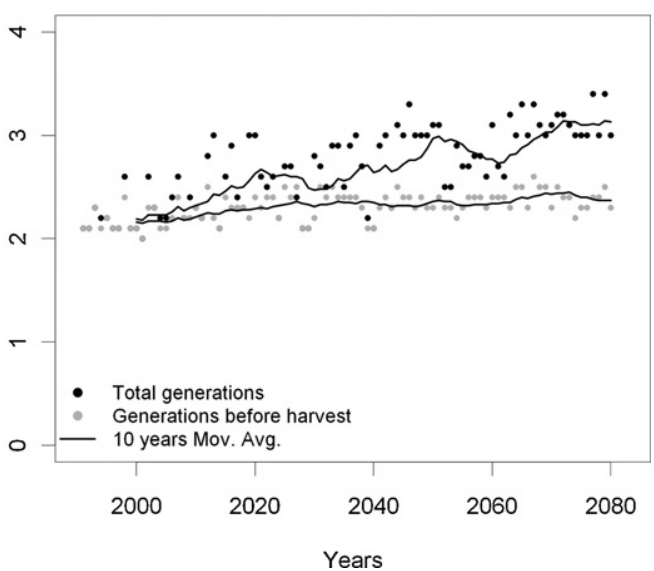

Fig. 2. Model simulations of total (black points) and pre-harvest (grey points) larval generations according to scenarios A2 and B2 for the two sites under study: San Michele (lower elevation), Cembra (higher elevation). 10-year moving average lines are superimposed on the series. The legend for all plots is displayed at the bottom left of the right plot.

more pronounced in the first than in the second case (Fig. 2). Regression analysis confirmed the significance of these increasing trends for both sites and scenarios, with rates of increase ranging from 0.05 generations/decade in San Michele - B2 to 0.18 generations/decade in Cembra - A2 (total generations) and from 0.03 generations/decade in San Michele B2 and Cembra B2 to 0.05 generations/decade in San Michele - A2 (pre-harvest generations) (Table 4). At the beginning of the projected period the total number of larval generations and the number of pre-harvest generations were often the same, due to a relatively late harvest date occurring around diapause induction (simulated on 21st September). Nevertheless, as temperature increased over the century, harvest date was predicted progressively earlier whereas the predicted timing of the photoperiod-driven diapause induction did not change, resulting in fewer pre-harvest than total generations. The site showing the highest increase in pre-harvest generations was San Michele in the A2 scenario (from 2.5 in the 1990 s to 2.9 in the 2070s), whereas
Table 4

Rates of change in the number of total and pre-harvest larval generations of European grapevine moth over the simulation period (1991-2080) (generations decade $^{-1}$ ), slope, $R^{2}$ and $p$-value of the linear regression model fitted to the simulated series for each site and scenario (all with $p<0.001$ ).

\begin{tabular}{|c|c|c|c|c|c|}
\hline & \multirow[t]{2}{*}{ Scenario } & \multicolumn{2}{|c|}{ Total generations } & \multicolumn{2}{|c|}{ Pre-harvest generations } \\
\hline & & Slope & $R^{2}$ & Slope & $R^{2}$ \\
\hline \multirow[t]{2}{*}{ San Michele } & A2 & 0.15 & 0.694 & 0.05 & 0.584 \\
\hline & B2 & 0.05 & 0.508 & 0.03 & 0.343 \\
\hline \multirow[t]{2}{*}{ Cembra } & $\mathrm{A} 2$ & 0.18 & 0.714 & 0.04 & 0.228 \\
\hline & B2 & 0.11 & 0.564 & 0.03 & 0.273 \\
\hline
\end{tabular}

Cembra showed only small increases in both scenarios (from 2.3 and 2.2 in the 1990 s to 2.4 and 2.4 in the 2070s, for A2 and B2, respectively) (Table 5 ).

The temporal overlap between resistant plant growth stages and first-generation larvae occurrence showed a high interannual

Table 5

European grapevine moth: mean number of total and pre-harvest generations \pm standard deviation, in three sample decades at the beginning, middle and end of the projection period (1991-2080).

\begin{tabular}{|c|c|c|c|c|c|c|c|}
\hline & & \multicolumn{2}{|l|}{$1991-2000$} & \multicolumn{2}{|l|}{$2021-2030$} & \multicolumn{2}{|l|}{$2071-2080$} \\
\hline & & Total generations & Pre-harvest generations & Total generations & Pre-harvest generations & Total generations & Pre-harvest generations \\
\hline \multirow[t]{2}{*}{ San Michele } & $\mathrm{A} 2$ & $2.79 \pm 0.28$ & $2.54 \pm 0.17$ & $3.1 \pm 0.19$ & $2.69 \pm 0.07$ & $3.95 \pm 0.10$ & $2.94 \pm 0.07$ \\
\hline & $\mathrm{B} 2$ & $2.69 \pm 0.14$ & $2.68 \pm 0.11$ & $2.79 \pm 0.12$ & $2.73 \pm 0.08$ & $3.63 \pm 0.28$ & $2.88 \pm 0.09$ \\
\hline \multirow[t]{2}{*}{ Cembra } & A2 & $2.33 \pm 0.33$ & $2.26 \pm 0.21$ & $2.70 \pm 0.25$ & $2.48 \pm 0.17$ & $3.66 \pm 0.28$ & $2.44 \pm 0.08$ \\
\hline & $\mathrm{B} 2$ & $2.19 \pm 0.16$ & $2.16 \pm 0.11$ & $2.47 \pm 0.25$ & $2.31 \pm 0.15$ & $3.13 \pm 0.16$ & $2.37 \pm 0.09$ \\
\hline
\end{tabular}


San Michele A2

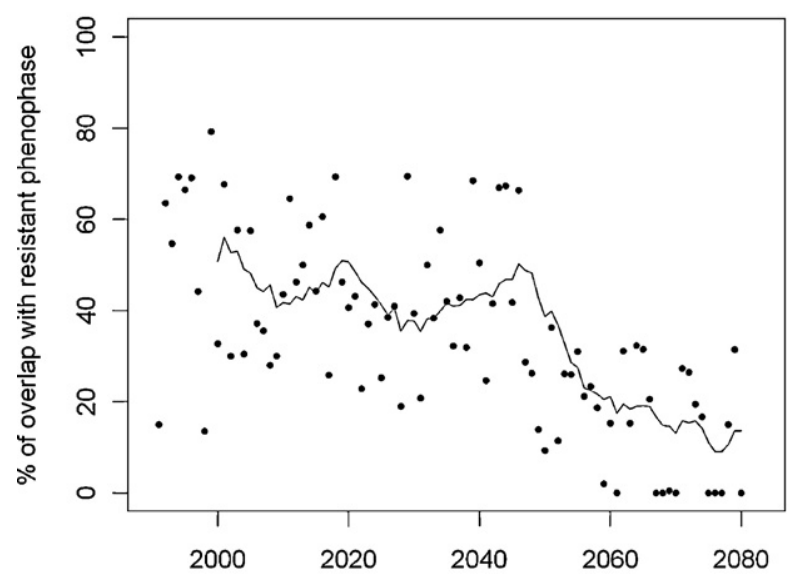

Cembra A2

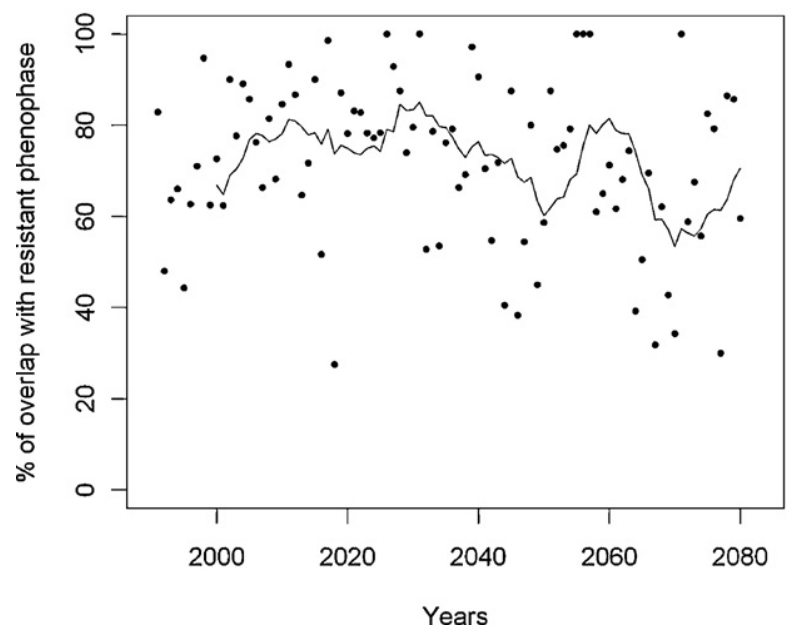

San Michele B2

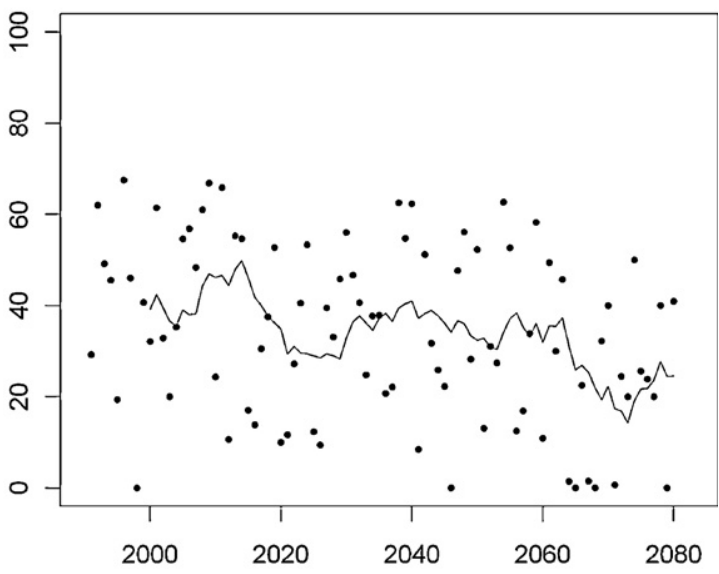

Cembra B2

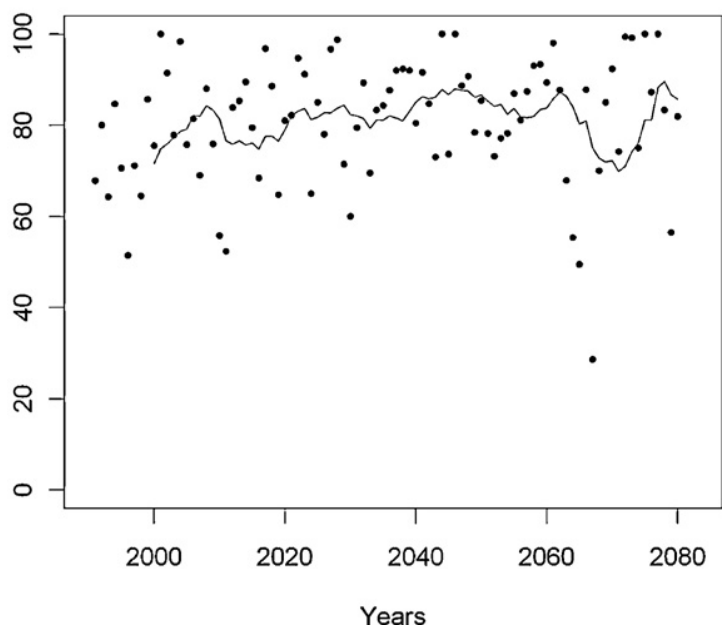

Fig. 3. Annual percentages of temporal overlap between European grapevine moth larvae and larvae-resistant phenophases in grapevines according to scenarios A2 and B2 for the two sites under study: San Michele (lower elevation) and Cembra (higher elevation). 10-year moving average lines are superimposed on the series.

variability at both sites and for both scenarios, ranging from total ( $100 \%$ overlap) to none ( $0 \%$ overlap). However, while San Michele showed a clear overall trend of decreasing overlap for both scenarios, Cembra did not, especially in the B2 scenario (Fig. 3). In fact, censored regression analysis confirmed significant negative trends for this variable only at San Michele (both scenarios) (Table 6). This pattern is also shown by the decrease in the mean percentages of temporal overlap between resistant growth stages and first-generation larvae, for San Michele in both scenarios (from 51 to $13 \%$ and from 39 to $25 \%$ from the 1990s to 2070s, for A2 and B2, respectively) contrasting with the lack of a clear trend in Cembra in the B2 scenario (nonsignificant increase from 71 to $86 \%$ from the 1990s to the 2070s).
Table 6

Rates of change in the percentage of overlap between larvae and the larvae-resistant phenophase over the simulation period (1991-2080) (\%overlap $\mathrm{yr}^{-1}$ ) (slope) and $R^{2}$ of the censored linear regression model fitted to the simulated series for each site and scenario.

\begin{tabular}{llll}
\hline & Scenario & Slope & $R^{2}$ \\
\hline San Michele & A2 & -0.543 & $0.393^{*}$ \\
Cembra & B2 & -0.232 & $0.090^{* *}$ \\
& A2 & -0.111 & 0.031 \\
& B2 & 0.075 & 0.017 \\
\hline
\end{tabular}

$p<0.001$

$p<0.05$.

Table 7

Powdery mildew: mean number of cycles and disease severity \pm standard deviation, in three sample decades at the beginning, middle and end of the projection period for the high and low-intermediate disease conduciveness (cond.) scenarios.

\begin{tabular}{|c|c|c|c|c|c|c|c|c|c|c|}
\hline & & \multicolumn{3}{|l|}{$1991-2000$} & \multicolumn{3}{|l|}{$2021-2030$} & \multicolumn{3}{|l|}{$2071-2080$} \\
\hline & & $\mathrm{N}^{\circ}$ cycles & $\begin{array}{l}\text { High cond. } \\
(\%)\end{array}$ & $\begin{array}{l}\text { Low- } \\
\text { intermediate } \\
\text { cond. }(\%)\end{array}$ & $\mathrm{N}^{\circ}$ cycles & $\begin{array}{l}\text { High pressure } \\
(\%)\end{array}$ & $\begin{array}{l}\text { Low- } \\
\text { intermediate } \\
\text { cond. }(\%)\end{array}$ & $\mathrm{N}^{\circ}$ cycles & $\begin{array}{l}\text { High cond. } \\
(\%)\end{array}$ & $\begin{array}{l}\text { Low- } \\
\text { intermediate } \\
\text { cond. }(\%)\end{array}$ \\
\hline San & $\mathrm{A} 2$ & $14.78 \pm 0.27$ & $97.64 \pm 0.09$ & $47.21 \pm 0.52$ & $14.66 \pm 0.28$ & $97.59 \pm 0.13$ & $46.94 \pm 0.75$ & $13.72 \pm 0.52$ & $96.84 \pm 0.84$ & $42.60 \pm 4.51$ \\
\hline Michele & B2 & $14.97 \pm 0.23$ & $97.70 \pm 0.07$ & $47.58 \pm 0.41$ & $14.73 \pm 0.20$ & $97.62 \pm 0.08$ & $47.14 \pm 0.44$ & $14.14 \pm 0.29$ & $97.31 \pm 0.25$ & $45.24 \pm 1.50$ \\
\hline \multirow[t]{2}{*}{ Cembra } & $\mathrm{A} 2$ & $13.40 \pm 0.19$ & $96.59 \pm 0.26$ & $40.93 \pm 1.53$ & $13.53 \pm 0.28$ & $96.74 \pm 0.29$ & $41.82 \pm 1.72$ & $12.98 \pm 0.37$ & $95.79 \pm 0.85$ & $36.67 \pm 4.23$ \\
\hline & B2 & $14.12 \pm 0.21$ & $97.31 \pm 0.14$ & $45.28 \pm 0.85$ & $14.02 \pm 0.22$ & $97.24 \pm 0.17$ & $44.82 \pm 1.03$ & $13.57 \pm 0.28$ & $96.79 \pm 0.35$ & $42.11 \pm 20.8$ \\
\hline
\end{tabular}



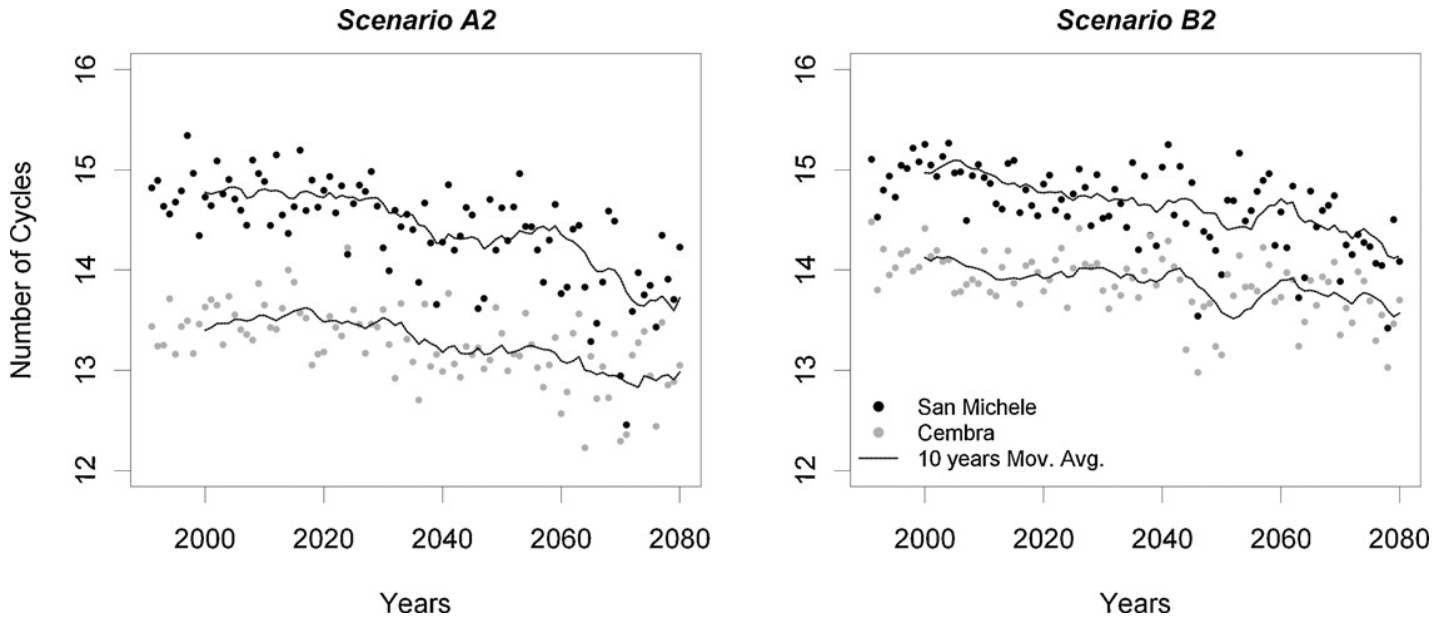

Fig. 4. Model simulations of the number of powdery mildew infection cycles according to scenarios A2 and B2 for the two sites under study: San Michele (lower elevation) (black symbols), Cembra (higher elevation) (grey symbols). 10-year moving average lines are superimposed on the series. The legend for both plots is displayed at the bottom left of the right plot.

\subsubsection{Powdery mildew}

At both sites, the duration of the susceptibility window to powdery mildew (i.e., $\mathrm{BBCH} 08$ to $8^{\circ}$ Brix) decreased between 20 and 25 days between the 1990s and the 2070s (for the B2 and A2 scenarios, respectively), mainly as an effect of an earlier $8^{\circ}$ Brix phenophase, as budburst advanced significantly by about one week only in the A2 scenario, for both San Michele and Cembra. Projections showed a decrease in the number of powdery mildew cycles as temperature increased over the simulation period. This trend was clear and significant $(p<0.001)$ at both sites and for both scenarios, though more pronounced for the A2 scenario $\left(R^{2}\right.$ ranging from 0.25 in Cembra B2 to 0.45 San Michele A2) (Fig. 4, Table 8). The site showing the largest decrease was San Michele for the A2 scenario (from 14.8 in the 1990s to 13.7 in the 2070s). In Cembra the effect of climate change on powdery mildew was less noticeable, for both the A2 (from 13.4 in the 1990s to 13 in the 2070s) and B2 scenarios (from 14.1 in the 1990s to 13.6 in the 2070s) (Table 7).

Simulations of disease severity showed significant decreasing trends in powdery mildew epidemics over the century (Fig. 5 and Table 8). However, whereas in a high disease conduciveness scenario, the decrease in disease severity was minimal (for example in San Michele for the A2 scenario it decreased from 97.6\% to 96.8\% from the 1990s to the 2070s), in the low-intermediate conduciveness scenario, changes were more noticeable (in San Michele for the A2 scenario it decreased from $47.2 \%$ to $42.6 \%$ from the 1990 s to the 2070s). Cembra showed a similar trend, with a pronounced decrease in disease severity, especially in the low-intermediate disease conduciveness scenario, and in the A2 scenario (from $40.9 \%$ in the 1990 s to $36.7 \%$ in the 2070 s).

\section{Discussion}

\subsection{European grapevine moth}

There is widespread concern that the predicted future warming will increase the pressure of insect pests and diseases on crops (Porter et al., 1991; Estay et al., 2009; Olesen et al., 2011). Increased temperatures and earlier onset of the growing season may reduce winter mortality, increase the rate of insect metabolism and development (Bale et al., 2002), and increase the number of generations of multivoltine species (Laštůvka, 2009). Recent works show that these changes are already taking place (Battisti et al., 2005; Raffa et al., 2008), and important insect-pests like the grapevine moth are producing additional broods compared to past decades (Pavan et al., 2006; Martin-Vertedor et al., 2010). For example, in southern Spain the extraordinarily high temperatures recorded in the spring-summer of 2006 resulted in European grapevine moth completing four complete generations as opposed to the usual three (Martin-Vertedor et al., 2010). In agreement with these observations, in our modelling projections rising temperatures resulted in a marked increase in the mean number of generations completed by this moth. However, when we considered the number of pre-harvest larval generations as opposed to the total number of larval generations, the increasing trend was not so pronounced. More specifically, the discrepancy between these two variables was initially minimal, but became larger over the projected period, most likely due to their different environmental controls. In fact, while the simulation of the total number of generations within a year was driven only by temperature and photoperiod, simulation of preharvest generations also depended on harvest time, which was in turn dependent on temperature during ripening. Increasing temperatures resulted in a marked advance in simulated harvest dates, but did not alter the timing of diapause induction, which is controlled by photoperiod. These results suggest that for Chardonnay, a potential increase in the pressure by European grapevine moth may be balanced by an earlier harvest and less time for larvae to produce damage. In agreement with this effect, Martin-Vertedor et al. (2010) noted that the four complete generations recorded in the warm 2006 in Spain were followed by a fifth incomplete adult generation after harvest, which presumably died without producing additional damage nor viable progeny. On the other hand, in viticultural areas where both late and early ripening varieties are grown, this might lead to higher pressure on later ripening rather than early ripening varieties. To assess this possibility, a modelling approach including different grapevine varieties within a specific area would be useful.

The projection of the timing of resistant plant growth stages in conjunction with the occurrence of first generation larvae made it possible to assess current and future patterns of plant-pest interactions. According to the simulations, currently, at all sites and for all scenarios there is a considerable temporal overlap between larvae and the flowering - fruit set window in Chardonnay. These results are supported by field observations from the study area. However, this overlap might decrease in the future at warmer, low elevation sites such as San Michele. In fact, while increased temperature resulted in a significantly earlier moth phenology, it advanced grapevine phenology to a lesser extent, resulting in a decrease in the synchrony between larvae and resistant phenological stages. The 

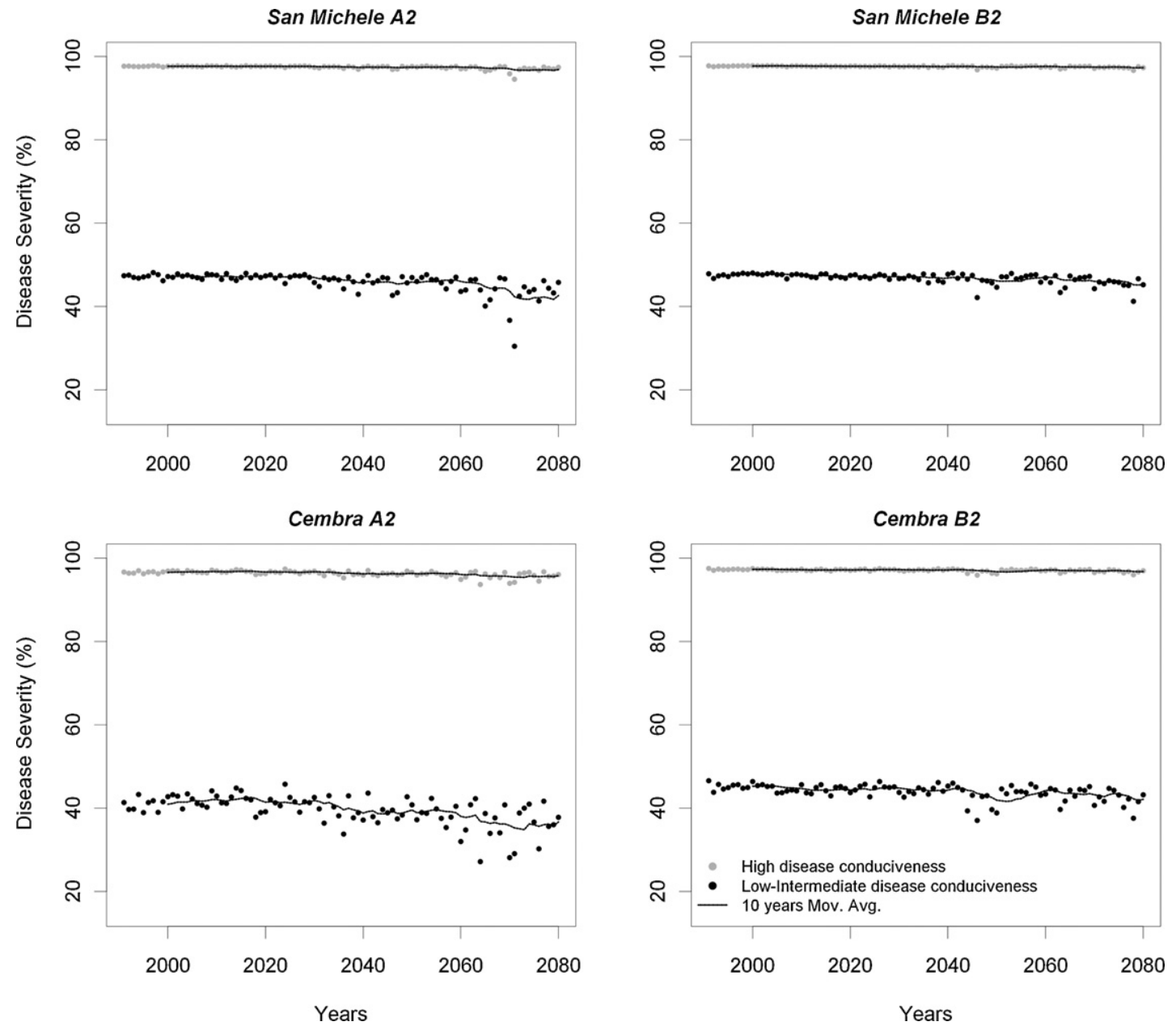

Fig. 5. Model simulations of powdery mildew severity (\%) in a scenario of low-intermediate conduciveness (black symbols) and high conduciveness (grey symbols) for the disease according to scenarios A2 and B2 for the two sites under study: San Michele (lower elevation), Cembra (higher elevation). 10-year moving average lines are superimposed on the series. The legend for all plots is displayed in the bottom left of the right plot.

same trend was predicted for Cembra, though it was not statistically significant in the simulation period and was only detected in the warmer A2 scenario. This simulation suggests that in the warmer, more profitable viticultural areas of the study region, increasing temperature might have a detrimental impact on crop yield due to increased asynchrony between the larvae-resistant growth stages of grapevine and larvae occurrence. Today, in warmer areas such as southern Italy or Spain, European grapevine moth adults are reported to emerge one month earlier than in northern Italy, in late March-early April, while larvae appear 1-2 weeks afterward (Moleas, 2005). However, Chardonnay flowering in these areas occurs only $2-3$ weeks earlier compared to northern Italy, so there is a shorter temporal overlap between larvae occurrence and resistant growth stages of grapevine. This situation resembles the one depicted by the model simulations. However, it is difficult to extrapolate current patterns of European grapevine moth infestations in areas like Sicily to the future situation of northern Italy because of the difference in local floras. In fact, these moths are generalists in their area of provenance (the Mediterranean basin), and lay their eggs and feed on a variety of host-plants, including Compositae, Convulvolaceae, Oleaceae, Rhamnaceae, Rosaceae, and Vitaceae (Stavridis and Savopoulou-Soultani, 1998). Thus, in Mediterranean areas the various local plant species might divert the first generation larvae from grapevines. A study by Pavan et al. (2009) reports that in the Veneto region (an area close to the study area, but slightly warmer), levels of infestation were higher on very early varieties with hairless inflorescences, like Chardonnay and Pinot gris. However, in none of the varieties tested

Table 8

Rates of change in powdery mildew disease severity over the simulation period (1991-2080) (\%overlap yr ${ }^{-1}$ ), slope and $R^{2}$ of the censored linear regression model fitted to the simulated series for each site and scenario ( $p<0.001$ in all cases).

\begin{tabular}{|c|c|c|c|c|c|c|c|}
\hline & \multirow[t]{2}{*}{ Scenario } & \multicolumn{2}{|c|}{ High cond. } & \multicolumn{2}{|c|}{ Low-intermediate cond. } & \multicolumn{2}{|c|}{ Number of cycles } \\
\hline & & Slope & $R^{2}$ & Slope & $R^{2}$ & Slope & $R^{2}$ \\
\hline San & A2 & -0.009 & 0.002 & -0.053 & 0.008 & -0.013 & 0.447 \\
\hline Michele & B2 & -0.004 & 0.001 & -0.026 & 0.004 & -0.009 & 0.379 \\
\hline \multirow[t]{2}{*}{ Cembra } & $\mathrm{A} 2$ & -0.014 & 0.002 & -0.075 & 0.012 & -0.008 & 0.304 \\
\hline & B2 & -0.006 & 0.001 & -0.034 & 0.007 & -0.006 & 0.254 \\
\hline
\end{tabular}


did larvae clusters exceed the economic injury level (100 larval nests per 100 clusters). Climate warming might exacerbate this vulnerability in some areas, like the alpine region, where there are few natural hosts of this pest and grapevines are the main food source.

\subsection{Powdery mildew}

The duration of the latency period is particularly important for powdery mildew, whose infection does not strictly depend on particular environmental conditions, like rainfall of the presence of free water on plant organs. Infection by this pathogen is virtually continuous and therefore the epidemic progression mostly depends on the daily dose of inoculum able to infect the host, which in turn depends on how many infection cycles have been completed, leading to sporulating powdery mildew colonies (Xu, 1999).

The more pronounced decrease in the mean number of infection cycles at the low elevation site can be related to the temperature response of latency duration, rather than to a difference in host susceptibility duration (showing a similar decrease across sites). Latency duration is minimal at optimal temperatures between 20 and $28^{\circ} \mathrm{C}$, and increases at temperatures below or above this range. Therefore, as the climate of San Michele (lower elevation) is currently in the optimal temperature range for powdery mildew development during the susceptible period of grapevine (spring-summer), a temperature increase would inevitably increase the latency duration. On the other hand, at the higher elevations of Cembra, a temperature increase from its currently cooler conditions does not imply such a large shift from optimal temperatures. Predicted severity of powdery mildew decreased more in the low-intermediate than in the high disease conduciveness scenario, due to the different effect that the decrease of mean number of annual cycles has on disease severity in the two scenarios (from 13.5-14.8 to 13.0-13.7 in the A2 scenario, for Cembra and San Michele, respectively, and from 14.1 and 15 to 13.6 and 14.1 in the B2 scenario for Cembra and San Michele, respectively): while in the highly conducive scenario an early start of the epidemic leads to highest disease severity from the 12th to 13th cycle onwards, in the low-intermediate scenario the maximum predicted severity occurs from the 14 th to 15 th cycle onwards. The fact that the decrease in simulated disease severity is higher for the A2 than the B2 scenario, but is similar across sites is counterintuitive, given the above mentioned difference in cycle decreases across sites (San Michele showing a larger decrease than Cembra). This effect is the result of the non-linearity and interaction between the different models used: in this case the higher damage decrease in $\mathrm{A} 2$ is related, at both sites, to the decrease in disease cycles occurring in correspondence with a faster decrease in disease severity (around the inflection point of the disease severity function).

These results suggest that climate change might decrease the severity of powdery mildew, especially during extreme years with particularly high temperatures, as those predicted by the more pessimistic ("business-as-usual") A2 scenario, and in the scenario with low-intermediate conduciveness for the disease. Similarly, Calonnec et al. (2008) modelled the interaction between grapevine and powdery mildew and found a lower impact of powdery mildew on grapevine on a particularly warm year (2003) compared to an average year (1998). This situation might occur more frequently if temperatures increase further, decreasing overall mildew severity.

\subsection{Conclusions}

The multiple interactions among pests, diseases and plants make it necessary to consider them jointly as a system, rather than separate elements (Grulke, 2011). This view finds support in the present simulations, which show a strong effect of host-plant development on pest and disease pressure and suggest that current interactions between host-pest and host-disease may be altered by climate change. Simulations suggested that in the warmer, more profitable viticultural areas of the study area, increasing temperature might have a detrimental impact on susceptibility to European grapevine moth due to increased asynchrony between the larvae-resistant growth stages of grapevines and larvae. On the other hand, the increase in pest pressure due to the increased number of generations might not be as severe as expected on the basis of the pest-model only, due to the advance in harvest dates which would limit damages of later generations, especially for early ripening grapevine varieties like Chardonnay. Simulations for powdery mildew showed a decrease in simulated disease severity especially in years with a later onset of the epidemics (assuming a low-intermediate disease conduciveness) and in the climate scenario with a higher temperature increase.

While the present simulations offer information on potential impacts of climate change on viticulture, they should be taken with caution due to the challenge of not being able to account for all of the factors affecting the host-pest and host-disease dynamics that might change in the future. Plant pathogens are generally highly adaptable and likely to exploit any compromise in plant defence caused by climate change. Instability of variation is common in many pathogens, although the mechanisms are often not known (Gregory et al., 2009). Many reports stress that pathogens show an increased ability to mutate and generate variants under stressed conditions (Hastings et al., 2000; Twiss et al., 2005). In particular, powdery mildew is able to reproduce both sexually and asexually producing a high number of spores, which increases the chances to produce strains adapted to changed climatic conditions. In particular, E. necator could adapt by developing a shorter duration of latency at higher temperatures, or by increasing asexual sporulation, which would in both cases result in an increase in disease severity. Also an earlier ascospore release adapted to an earlier bud break of vines could led to a greater number of infection cycles than those predicted in this work.

Similar to pathogens, insects are generally adaptable organisms (Bradshaw and Holzapfel, 2008; Laštůvka, 2009). While climate change might result in a disruption of their synchrony with the host, adaptive processes are likely to quickly restore this synchrony (Robinet and Roques, 2010). For example, in Japan, Gomi et al. (2007) reported a decrease in the length of the critical photoperiod for diapause induction in the fall webworm (Hyphantria cunea) which enabled this species to produce one additional brood per year and exploit warmer temperatures.

Indeed, predicting potential consequences of climate change on the interaction between trophic levels is a complicated matter because of the number of factors involved. A range of environmental factors not directly considered by the models employed in this study might affect trophic interactions in the future. For example, elevated $\mathrm{CO}_{2}$ concentrations, such as those predicted in the future, cause a decrease in leaf nitrogen and increase carbohydrates and phenolics, with potential effects on the interaction between insect herbivore and plants (Bezemer and Jones, 1998). Changes in precipitation and humidity might also impact the phenology and population dynamics of both pest/pathogen and host. In order to model these interactions, we need to improve our understanding of the whole system, through experiments and observations taking into account different trophic levels. Similarly, modelling studies aimed at predicting the impacts of climate change on agricultural ecosystems should integrate all these responses (Hoover and Newman, 2004; Ponti et al., 2009) to obtain a more realistic picture of all potential effects and better assist the development of mitigation policies. 


\section{Acknowledgements}

The authors wish to thank Gianfranco Anfora, Fabio Zottele, Len Coop, Friedrich Menke, Francesco Penner, Maurizio Bottura, Francesco Fellin for data supply, advice and proofreading.

\section{References}

Analytis, S., 1980. Obtaining of sub-models for modeling the entire life cycle of a pathogen. J. Plant Dis. Prot. 87, 371-382.

Anfora, G., Schmidt, S., Ioratti, C., 2007. Morfologia e biologia. In: Anfora, G., Angeli, G., Baldessari, M., Ioriatti, C., Marchesini, E., Mattedi, L., Menke, F., Mescalchin, E., Schmidt, S., Tasin, M., Varner, M. (Eds.), Le tignole della vite. , pp. 22-31.

Arca, B., Cossu, A., Delrio, G., Locci, L., 1993. Individuazione dei gradi giorno relativi allo sviluppo della Lobesia botrana (Den. Et Schiff.) in Sardegna. Atti Convegno Nazion. Protezione delle colture: osservazioni, previsioni, decisioni, Pescara 7-8 Ottobre, pp. 325-334 (http://www.sar.sardegna.it/pubblicazioni/notetecniche/nota3/pag018.asp).

Bale, J., Masters, G., Hodkinson, I., Awmack, C., Bezemer, T., Brown, V., Butterfield, J., Buse, A., Coulson, J., Farrar, J., Good, J.E.G., Harrington, R., Hartley, S., Jones, T.H., Lindroth, R.L., Press, M.C., Symrnioudis, I., Watt, A.D., Whittaker, J.B., 2002 Herbivory in global climate change research: direct effects of rising temperature on insect herbivores. Glob. Chang. Biol. 8, 1-16.

Baker, R.H.A., Sansford, C.E., Gioli, B., Migletta, F., Porter, J.R., Ewert, F.,2005. Combining a disease model with a crop phenology model to assess and map pest risk: Karnal bunt disease (Tilletia indica) of wheat in Europe. In: Plant Protection and Plant Health in Europe: Introduction and Spread of Invasive Species, Symposium Proceedings No. 81 (pp. 89-94). BCPC Alton, Hampshire, UK.

Battisti, A., Stastny, M., Netherer, S., Robinet, C., Schopf, A., Roques, A., Larsson, S. 2005. Expansion of geographic range in the pine processionary moth caused by increased winter temperatures. Ecol. Appl. 15, 2084-2096.

Bradshaw, W.E., Holzapfel, C.M., 2008. Genetic response to rapid climate change: it's seasonal timing that matters. Mol. Ecol. Jan. 17, 157-166.

Bendek, C., Campbell, P., Torres, R., Donoso, A., Latorre, B.A., 2007. The risk assessment index in grape powdery mildew control decisions and the effect of temperature and humidity on conidial germination of Erysiphe necator. SJAR $5,522-532$

Bezemer, T.M., Jones, T.H., 1998. Plant-insect herbivore interactions in elevated atmospheric $\mathrm{CO}_{2}$ : quantitative analyses and guild effects. Oikos 82, 212-222.

Caffarra, A., Eccel, E., 2010. Increasing the robustness of phenological models for Vitis vinifera cv Chardonnay. Int. J. Biometeorol. 54, 255-267.

Caffarra, A., Eccel, E., 2011. Projecting the impacts of climate change on the phenology of grapevine in a mountain area. Aust. J. Grape Wine Res. 17, 52-61.

Caffi, T., Rossi, V., Leger, S.E., Bugiani, R., 2011. A mechanistic model simulating ascosporic infections by Erysiphe necator, the powdery mildew fungus of grapevine. Plant Pathol. 60, 522-531.

Campbell, P., Bendek, C., Latorre, B.A., 2006. Risk of powdery mildew (Erysiphe necator) outbreaks on grapevine in relation to cluster development. Cien. Inv. Agr. 34, 1-6.

Calonnec, A., Cartolaro, P., Naulin, J.M., Bailey, D., Langlais, M., 2008. A host-pathogen simulation model: powdery mildew of grapevine. Plant Pathol. 57, 493-508.

Carisse, O., Bacon, R., Lefebvre, A., Lessard, K., 2009. A degree-day model to initiate fungicide spray programs for management of grape powdery mildew (Erysiphe necator). Can. J. Plant Pathol. 31, 186-194.

Carroll, J.E., Wilcox, W.F., 2003. Effects of humidity on the development of grapevine powdery mildew. Phytopathology 93, 1137-1144.

Chakraborty, S., Tiedermann, A.V., Teng, P.S., 2000. Climate change: potential impact on plant diseases. Env. Poll. 108, 317-326.

Chellemi, D.O., Marois, J.J., 1991. Development of a demographic growth model for Uncinula necator by using a microcomputer sreadsheet program. Phytopathology $81,250-254$.

Chuine, I., Cour, P., Rousseau, D.D., 1998. Fitting models predicting the dates of flowering of temperate-zone tree species using simulating annealing. Plant Cell Environ. 21, 455-466.

Coop, L., 2009. Integrated Plant Protection Center at Oregon State University and the WRIPM Centers. http://uspest.org/cgi-bin/ddmodel.pl (accessed 2009).

Cortesi, P., Gadoury, D.M., Seem, R.C., Pearson, R.C., 1995. Distribution and retention of cleistothecia of Uncinula necator on the bark of grapevines. Plant Dis. 79, 15-19.

Cossu, Q.A., Delrio, G., Di Cola, G., Gilioli, G., 1999. Modelli matematici nella protezione integrata delle colture in Sardegna. Collana di Agrometeorologia per la Sardegna, Nota Tecnica 3.

Delbac, L., Lecharpentier, P., Thiery, D., 2010. Larval instars determination for the European Grapevine Moth (Lepidoptera: Tortricidae) based on the frequency distribution of head-capsule widths. Crop Prot. 29, 623-630.

Delp, C.J., 1954. Effect of temperature and humidity on the grape powdery mildew fungus. Phytopathology 44, 615-626.

Deseo, K.V., Brunelli, F.M.A., Bertaccini, A., 1981. Observations on the biology and diseases of Lobesia botrana Den and Schiff. (Lepidoptera: Tortricidae) in centralnorth Italy. Acta Phytopathol. Hung. 16, 405-431.

Dukes, J.S., Pontius, J., Orwig, D., et al., 2009. Responses of insect pests, pathogens, and invasive plant species to climate change in the forests of northeastern North America: what can we predict? Can. J. For. Res. 39, 231-248.
Easterling, W.E., Aggarwal, P.K., Batima, P., Brander, K.M., Erda, L., Howden, S.M Kirilenko, A., Morton, J., Soussana, J.-F., Schmidhuber, J., Tubiello, F.N., 2007. Food, fibre and forest products. In: Parry, M.L., Canziani, O.F., Palutikof, J.P., van der Linden, P.J., Hanson, C.E. (Eds.), Climate Change 2007: Impacts, Adaptation and Vulnerability. Contribution of Working Group II to the Fourth Assessment Report of the Intergovernmental Panel on Climate Change. Cambridge University Press, Cambridge, UK, pp. 273-313.

Eccel, E., Rea, R., Caffarra, A., e Crisci, A., 2009. Risk of spring frost to apple production under future climate scenarios: the role of phenological acclimation. Int. J. Biometeorol. 53, 273-286.

Estay, S.A., Lima, M., Labra, F.A., 2009. Predicting insect pest status under climate change scenarios: combining experimental data and population dynamics modelling. J. Appl. Entomol. 133, 491-499.

Fernandez-Gonzalez, M., Rodriguez-Rajo, J., Jato, V Aira, M.J., 2009. Incidence of fungals in a vineyard of the denomination of origin Ribeiro (Ourense - NorthWestern Spain). Ann. Agric. Environ. Med. 16, 263-271.

Fuhrer, J., 2003. Agro-ecosystem response to combinations of elevated $\mathrm{CO}_{2}$, ozone and global climate change. Agric. Ecosyst. Environ. 97, 1-20.

Gabel, B., Roehrich, R., 1995. Sensitivity of grapevine phenological stages to larvae of European grapevine moth, Lobesia botrana Den. et Schiff. (Lep., Tortricidae) J. Appl. Entomol. 119, 127-130.

Gadoury, D.M., Pearson, R.C., 1988. Initiation, development, dispersal and surviva of cleistothecia of Uncinula necator in New York vineyards. Phytopathology 78, 1413-1421.

Gadoury, D.M., Seem, R.C., Pearson, R.C., Wilcox, W.F., Dunst, R.M., 2001. Effects of powdery mildew on vine growth, yield, and quality of concord grapes. Plant Dis. 85, 137-140.

Gadoury, D.M., Seem, R.C., Ficke, A., Wilcox, W.F., 2003. Ontogenic resistance to powdery mildew in grapes berries. APS 93, 5 .

Gomi, T., Nagasaka, M., Fukuda, T., Hagihara, H., 2007. Shifting of the life cycle and life-history traits of the fall webworm in relation to climate change. Entomol. Exp. Appl. 125, 179-184.

Gregory, P.J., Johnson, S.N., Newton, A.C., Ingram, J.S.I., 2009. Integrating pests and pathogens into the climate change/food security debate. J. Exp. Bot. 60 2827-2838.

Garrett, K.A., Nita, M., De Wolf, E.D., Gomez, L., Sparks, A.H., 2009. Plant pathogens as indicators of climate change. In: Climate Change: Observed Impacts on Planet Earth. Elsevier, pp. 425-437.

Grulke, N.E., 2011. The nexus of host and pathogen phenology: understanding the disease triangle with climate change. New. Phytol. 189, 8

Gutierrez, A.P., Ponti, L., Cossu, Q.A., 2009. Effects of climate warming on Olive and olive fly (Bactrocera oleae (Gmelin)) in California and Italy. Climatic Change 95, 195-217.

Hall, A., Jones, G., 2008. Effect of potential atmospheric warming on temperaturebaed indices describing Australian winegrape growing conditions. Aust. J. Grape Wine Res. 14, 1-23.

Hastings, P.J., Bull, H.J., Klump, J.R., Rosenberg, S.M., 2000. Adaptive amplification: an inducible chromosomal instability mechanism. Cell 103, 723-731.

Hoover, J.K., Newman, J.A., 2004. Tritrophic interactions in the context of climate change: a model of grasses, cereal Aphids and their parasitoids. Glob. Change Biol. 10, 1197-1208.

Kang, Y.H., Khan, S., Ma, X.Y., 2009. Climate change impacts on crop yield crop water productivity and food security - A review. Prog. Nat. Sci. 19, $1665-1674$

Laštůvka, Z., 2009. Climate change and its possible influence on the occurrence and importance of insect pests. Plant. Prot. Sci. 45, 53-62.

Logan, J.A., Wollkind, D.J., Hoyt, S.C., Tanigoshi, L.K., 1976. An analytical model for description of temperature dependent rate phenomena in arthropods. Env. Entomol. 5, 1133-1140.

Maracchi, G., Sirotenko, O., Bindi, M., 2005. Impacts of present and future climate variability on agriculture and forestry in the temperate regions: Europe. Climatic Change 70, 117-135.

Martin-Vertedor, D., Ferrero-Garcia, J.J., Torres-Vilas, L.M., 2010. Global warming affects phenology and voltinism of Lobesia botrana in Spain. Agric. For. Entomol. $12,169-176$.

Menke, F., 2007. Un esempio pratico: la lotta alle tignole della vite in Alto Adige. In Anfora, G., Angeli, G., Baldessari, M., Ioriatti, C., Marchesini, E., Mattedi, L., Menke, F., Mescalchin, E., Schmidt, S., Tasin, M., Varner, M. (Eds.), Le tignole della vite. pp. 32-39.

Metropolis, N., Rosenbluth, A.V., Rosenbluth, M.N., Teller, A.H., Teller, E., 1953. Equation of state calculations by fast computing machines. J. Chem. Phys. 21 1087-1092.

Moleas, T., 2005. Le tignole della vite: notizie bioetologiche e tecniche di controllo. In: Ragusa, S., Tsolakis, H. (Eds.), La difesa della vite dagli artropodi dannosi. , pp. 97-147.

Moschos, T., Souliotis, C., Broumas, T., Kapothanassi, V., 2004. Control of the European grapevine moth Lobesia botrana in Greece by the mating disruption technique: a three-year survey. Phytoparasitica 32, 83-89.

Nakicenovic, N., Swart, R., 2000. Special Report on Emission Scenarios. Cambridge University Press, UK, pp. 570-579.

Olesen, J.E., Bindi, M., 2002. Consequences of climate change for European agricultural productivity, land use and policy. Eur. J. Agron. 16, 239-262.

Olesen, J.E., Trnka, M., Kersebaum, K.C., Skjelvåg, A.O., Seguin, B., Peltonen-Sainio, P. Rossi, F., Kozyra, J., Micale, F., 2011. Impacts and adaptation of European crop production systems to climate change. Eur. J. Agron. 34, 96-112. 
Panter, S.N., Jones, D.A., 2002. Age-related resistance to plant pathogens. Adv. Bot. Res. 38, 251-280.

Pavan, F., Floreani, C., Barro, P., Zandigiacomo, P., Dalla Montà, L., 2010. Influence of generation and photoperiod on larval development of Lobesia botrana. Env. Entomol. 39, 1652-1658.

Pavan, F., Stefanelli, G., Cargnus, E., Villani, A., 2009. Assessing the influence of inflorescence traits on the susceptibility of grape to vine moths. J. Appl. Entomol. 133, 394-401.

Pavan, F., Zandigiacomo, P., Dalla Montà, L., 2006. Influence of the grape-growing area on the phenology of Lobesia botrana second generation. Bull. Insectol. 59, 105-109.

Pearson, R.C., Goheen, A.C., 1988. Compendium of Grape Diseases. A.P.S.

Ponti, L., Cossu, Q.A., Gutierrez, A.P., 2009. Climate warming effects on the Olea europea-Bactrocera oleae system in Mediterranean islands: Sardinia as an example. Glob. Change Biol. 15, 2874-2884

Pope, V., Gallani, M.L., Rowntree, P.R., Stratton, R.A., 2000. The impact of new physical parameterizations in the Hadley Centre climate model: HadAM3. Clim. Dyn. 16, 123-146.

Porter, J.H., Parry, M.L., Carter, T.R., 1991. The potential effects of climatic change on agricultural insect pest. Agric. For. Meteorol. 57, 221-240.

Raffa, K.F., Aukema, B.H., Bentz, B.J., Carroll, A.L., Hicke, J.A., Turner, M.G., Romme, W.H., 2008. Cross-scale drivers of natural disturbances prone to anthropogenic amplification: the dynamics of bark beetle eruptions. Bioscience 58, 501-517.

Rapagnani, M.R., Caffarelli, V., Barlattini, M., 1988. Lobesia botrana (Den. et Schiff.): studio in laboratorio del ciclo di sviluppo in funzione della temperatura. In: Atti XV Congr. Naz. Ital. Entomol. L'Aquila, pp. 973-980.

Robinet, C., Roques, A., 2010. Direct impacts of recent climate warming on insect populations. Integr. Zool. 5, 132-142.

Roditakis, N.E., Karandinos, M.G., 2001. Effects of photoperiod and temperature on pupal diapause induction of grape berry moth Lobesia botrana. Physiol. Entomol. 26, 329-340.

Roehrich, R., 1969. La diapause de l'Eudémis de la Vigne Lobesia botrana Schiff. (Lép.: Tortricidae): induction et élimination. Ann. Zool. Ecol. Anim. 1, 419-431.
Salinari, F., Giosue, S., Tubiello, F.N., Rettori, A., Rossi, V., Spanna, F., Rosenzweig, C., Gullino, M.L., 2006. Downy mildew (Plasmopara viticola) epidemics on grapevine under climate change. Global Change Biol. 12, 1299-1307.

Sall, M.A., 1980. Epidemiology of grape powdery mildew: a model. Phytopathology $70,338-342$.

Schnedler, W., 2005. Likelihood estimation for censored random vectors. Econ. Rev. 24, 195-217.

Stavridis, D.G., Savopoulou-Soultani, M., 1998. Larval performance on and oviposition preference for known and potential hosts by Lobesia botrana (Lepidoptera: Tortricidae). Eur. J. Entomol. 95, 55-63.

Thomson, S.V., 2000. Epidemiology of fire blight. In: Vanneste, J.L. (Ed.), Fire Blight the Disease and its Causative agent, Erwinia amylovora. CABI Publishing, Wallingford, UK, pp. 9-36.

Torres-Vila, L.M., Rodriguez-Molina, M.C., McMinn, M., Rodriguez-Molina, A., 2004 Larval food source promotes cyclic seasonal variation in polyandry in the moth Lobesia botrana. Oxford J. 16, 114-122.

Twiss, E., Coros, A.M., Tavakoli, N.P., Derbyshire, K.M., 2005. Transposition is modulated by a diverse set of host factors in Escherechia coli and is stimulated by nutritional stress. Mol. Microbiol. 57, 1593-1607.

Webb, L., Whetton, P., Barlow, E.W.R., 2008. Climate change and wine grape quality in Australia. Clin. Res. 36, 99-111.

$\mathrm{Xu}, 1999$. Effects of temperature on the latent period of the rose powdery mildew pathogen, Sphaerotheca pannosa. Plant Pathol. 48, 662-667.

Yamamura, K., Yokozawa, M., 2002. Prediction of a geographical shift in the prevalence of rice stripe virus disease transmitted by the small brown planthopper, Laodelphax striatellus (Fallen) (Hemiptera: Delphacidae), under global warming. App. Entomol. Zool. 37, 181-190.

Yuen, J., Hughes, G., 2002. Bayesian analysis of plant disease prediction. Plant Pathol. $51,407-412$.

Woiwod, I., 1997. Detecting the effects of climate change on Lepidoptera. J. Insect. Conserv. 1, 149-158. 